JOAN AFFERICA

\title{
Academician Lev Vladimirovich Cherepnin, 1905-1977: In Memoriam
}

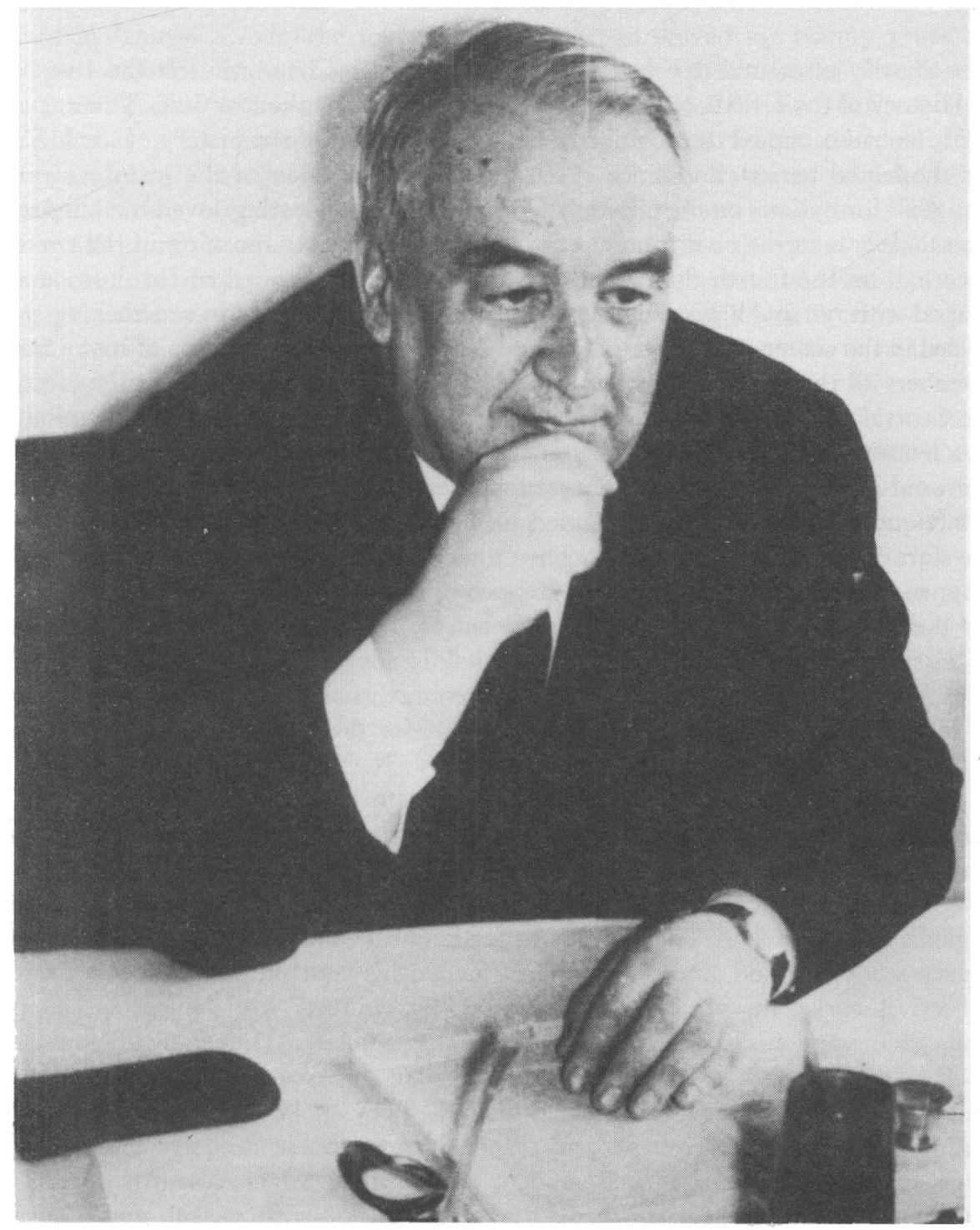

On June 12, 1977, L. V. Cherepnin died at the age of seventy-two. One of the most distinguished representatives of the Soviet historical profession, he made a significant contribution to the establishment of standards for the critical use and publication of primary sources and to the formulation of major propositions concerning the nature of Russian feudalism and, more narrowly, the formation of the Russian centralized state. A devoted historian of prodigious energy and stagger- 
ing output, his legacy in scholarship and in the organization of historical research, accumulated over several decades, will command the attention of historians and students of Soviet historiography and will affect the continuing investigation of Russia's twelfth through seventeenth centuries for many years to come.

\section{i}

Shortly after mid-day on June 16, 1977, L. V. Cherepnin left the Institute of History of the USSR of the Academy of Sciences for the last time. There, since 1951 , he had occupied the position of head of the sector of the history of the USSR for the feudal period, and since 1969, head of the division of the history of precapitalist formations on the territory of the USSR. His death grieved the hundreds who took part in the civil funeral on that sunny Thursday morning in the conference hall on the fourth floor. The walls of the room, emptied of furniture, were draped with red and black hangings. The open.coffin, encircled in red ruching, was placed in the center of the room. The body was covered with flowers of many hues. Members of the honor guard, led by S. S. Khromov from the culture section of the Central Committee of the CPSU, entered the room at intervals of five minutes in solemn procession, bearing on a cushion the insignia of honors bestowed on the deceased during his lifetime. They took their posts at the four corners of the catafalque. Vigilant women struggled to clear the path of the honor guard until the start of the formal observance. The crowd quieted. The recorded funeral music stopped. Distinguished colleagues stepped forward to pronounce the eulogies: for the Presidium of the Academy of Sciences, Iu. V. Bromlei; for the Institute of History, its director A. L. Narochnitskii; for the journal Istoriia SSSR, I. D. Kovalchenko ; for the sector, A. A. Preobrazhenskii ; for the History Faculty of Moscow State University, N. P. Eroshkin; for the Institute of History of the Moldavian Academy of Sciences, its director V. K. Vizer; for the many students of the deceased, V. D. Nazarov; for the Historical-Archival Institute, E. I. Kamentsova; and, last, for the Secretariat of the Institute of History, L. M. Gavrilov.

The speakers recalled Cherepnin's brilliant career as scholar, academic organizer, and teacher. They stressed the significance of his work in the areas of source study, method, and theory. They lauded his contribution to the institute's collective works, his principal monographs, his contests with bourgeois conceptions of history, his fruitful work with young scholars. They ranked him with B. D. Grekov and M. N. Tikhomirov as a giant of Soviet historical scholarship and claimed for him a place in world history. They spoke of his personal traits: dignity, simplicity, selflessness, and responsiveness to the needs of others, none more movingly than his former student and protégé V. D. Nazarov. After an hour the funeral cortege formed-the open trucks with casket and flowers, two small buses of mourners. The slow journey under militia escort ended at the crematorium on the distant edge of the city. There a small group in the "ritual hall" heard the last speakers-from the Central State Archives of Ancient Acts, from Moscow State University, from the Historical-Archival Institute. Then the matron announced the "farewell," hammered shut the coffin, and pushed it forward and out of sight. 
ii

The eulogists' principal themes were elaborated in published obituaries, which in turn drew upon recent biographical essays commemorating important occasions in Cherepnin's life and career--his sixtieth and seventieth birthdays and his election to the Academy of Sciences. ${ }^{1}$ The most extensive obituary appeared in Istoriia SSSR, the journal Cherepnin had served for twenty years as contributor and editorial board member. It was written by two of his closest associates, V. T. Pashuto and V. D. Nazarov. The senior of the two, Corresponding Member of the Academy of Sciences Pashuto, appears first in the published bibliography of Cherepnin's works. ${ }^{2}$ With A. A. Zimin, Pashuto composed the principal review of part one of Cherepnin's doctoral dissertation for Voprosy istorii (1949, no. 9). Pashuto's name recurs frequently in subsequent decades as collaborator in major collective undertakings of the Institute of History and, more particularly, as coauthor of several articles analyzing key problems on the definition of Russian feudalism and the principle of party-mindedness in historical research. According to Cherepnin's published bibliography (which, unfortunately, stops in 1975), their collaboration began in 1951 with an important article during an all-union debate on periodization of the feudal epoch, ${ }^{3}$ and it ends with a report for the International Congress of Historians in San Francisco on the formation of the Russian centralized state. ${ }^{4}$ The junior author of the obituary, V. D. Nazarov, had also written earlier about Cherepnin-in the annual of the Great Soviet Encyclopedia (1974) and Voprosy istorii (1975). As Cherepnin's stu-

1. See, among others, P. G. Ryndziunskii, "Tvorcheskii put' sovetskikh uchenykh: L. V. Cherepnin," Voprosy istorii, 1965, no. 6, pp. 179-80 (hereafter cited as VI) ; Sovetskaia istoricheskaia entsiklopediia, vol. 15 (Moscow, 1968), pp. 840-41; N. M. Druzhinin and V. T. Pashuto, "K semidesiatiletiiu L. V. Cherepnina," in Obshchestvo i gosudarstvo feodal'noi Rossii: Sbornik statei, posviashchennyi 70-letiiu akademika L'va Vladimirovicha Cherepnina (Moscow, 1975), pp. 3-8 (hereafter cited as Obshchestvo); V. D. Nazarov and V. L. Ianin, "K semidesiatiletiiu akademika L. V. Cherepnina," $V I, 1975$, no. 5, pp. 149-55; unsigned obituary in VI, 1977, no. 7, pp. 219-20; V. T. Pashuto and V. D. Nazarov, "Pamiati starshego druga: O L've Vladimiroviche Cherepnine," Istoriia SSSR, 1978, no. 1, pp. 144-56 (hereafter cited as I SSSR); S. M. Kashtanov, "Lev Vladimirovich Cherepnin (1905-1977)," Arkheograficheskii ezhegodnik za 1977 (Moscow, 1978), pp. 378-80.

2. A selected bibliography of Cherepnin's works may be found in Feodal'naia Rossiia vo vsemirno-istoricheskom protsesse: Sbornik statei, posviashchennyi L'vu Vladimirovichu Cherepninu (Moscow, 1972), pp. 7-27. It continues in Obshchestvo, pp. 344-47.

3. $V I, 1951$, no. 2 , pp. $52-80$.

4. The report was published in $V I, 1978$, no. 2, pp. 41-53. They are also mentioned together in the report of the meeting of the Scholarly Council of the Institute of History, December 1948 ("V Institute istorii Akademii nauk SSSR," VI, 1948, no. 12, p. 172). According to a recent biography, Pashuto's monographs and articles treat the complex of theoretical and concrete-historical questions of the emergence of early feudal societies and states, the role and significance of the ancient Rus' state in the system of international relations, the most important methodological problems of the historical process in feudal Russia, the mastery of the Leninist conception of Russian history, and problems of party-spiritedness in historical science, and so forth (see Vestnik akademii nauk SSSR, 1977, no. 3, pp. 38-39 (hereafter cited as Vestnik). 
dent and associate at the Institute of History, Nazarov had worked closely with Cherepnin in recent years, among other assignments composing with Cherepnin and Pashuto an article entitled "Problems of the Sociopolitical History of Feudal Russia in the Most Recent Historiography" (1976). "The published essays devoted to Cherepnin's life and work, particularly the several essays by Pashuto and Nazarov, amply characterize the honored place reserved for Cherepnin in Soviet historical scholarship.

All obituaries depict Cherepnin at the peak of his professional attainments. The last major monograph, Land Assemblies of the Russian State in the Sixteenth and Seventeenth Centuries, had been submitted to the institute just prior to his death. It was the logical culmination of decades of study of Russian institutions, now with special attention to their comparative aspects. The volume followed over three hundred fifty publications, a number that will increase with the posthumous appearance of other works. The printed assessments of Cherepnin's career stress his extraordinary breadth of scholarly interests and the various loci for developing those interests: the writing desk from which streamed thousands of pages of monographs, essays in collective works, editions of documents, articles, and texts in the auxiliary historical disciplines and historiography; the scholarly council of numerous research institutions which helped design and implement research plans; the editorial board of numerous journals which provided the forum for ongoing discussion; the collegium of collective series and encyclopedias which fixed periodically the latest points of resolution; the classroom which generated and refined ideas and nurtured a growing school. Published tributes record a multiplicity of activities by a historian of unusual energy and drive, a man of intellectual acuity and deep humanity. He is emulated by two generations of students for his standards of professional and personal conduct.

At the time of his death, Cherepnin had been academician since 1972, a party member since 1957. He was granted the honorary title "Distinguished Scholar of the RSFSR" (1970). He was named laureate of the Lomonosov Prize of Moscow State University (1958) in recognition of two academic courses at the university which led to major publications-Russian Historiography to the Nineteenth Century (1957) and Russian Paleography (1956). He won the State Prize of the Moldavian SSR in the area of science and technology (1972) for his role in preparing volume one of History of the Moldavian SSR (1965). On the occasion of his seventieth birthday, April 12, 1975, he received the Order of the Red Banner of Labor for service in the development of Soviet historical science and preparation of scientific cadres.

His extensive teaching experience included the Moscow Historical-Archival Institute (from 1942), the History Faculty of Moscow University (1944-70), the Moscow Institute of International Relations (1946-52), the Academy of Social Sciences of the Central Committee CPSU (1946-59 and from 1970), and also the Higher Party School of the Central Committee CPSU.

His prodigious organizational experience began in earnest with his appointment in 1951 as director of the Institute of History's sector for the study of the history of the USSR in the feudal epoch. This key academic position influenced the direction of national medieval studies. As academician, he was especially

5. It was published in $V I, 1976$, no. 4, pp. 25-48. 
active in the administrative work of the division of history, serving on scholarly councils, directing serial publication of historical documents, working with the Archeographic Commission, and coordinating scientific research, teaching, publishing, and archival work. The following list of his administrative activities in recent decades is selective: ten scholars' councils, including those of the Institute of History (renamed the Institute of History of the USSR in 1969), the Institute of Slavic and Balkan Studies, the Department of the History of the USSR of the Academy of Social Sciences of the Central Committee CPSU and Moscow University, eight councils on scientific problems and methodology attached to the division of the Academy, the Main Archival Administration of the Council of Ministers, the Ministry of Education, and other archives, libraries, and branch research institutes. He took part in the selection of Lenin and State Prize winners under the Council of Ministers, served as consulting editor for the Soviet Historical Encyclopedia and the third edition of the Great Soviet Encyclopedia; he joined the editorial boards of the leading journals Voprosy. istorii, Istoriia SSSR, and Istoricheskie zapiski.

Cherepnin's scholarly-organizational activity brought him international as well as national prominence. He participated in scholarly publications of the countries of Eastern Europe. He was a member of the International Association of Slavic Studies (from 1965) and the International Commission on the History of Representative and Parliamentary Institutions (from 1958), serving as vice president of the latter from 1970 . He was particularly active on the National Committee of Historians of the Soviet Union and represented his country at many international congresses, conferences, and symposia. In that capacity he traveled to Rome, Stockholm, Vienna, Paris, Brussels, London, Venice, and San Francisco.

The taxing burden of weighty administrative responsibilities, typically assumed by many of the most productive leaders in the historical profession, in no way interrupted the bounteous and regular appearance of major and minor publications by Cherepnin on a broad range of questions. His research interests included, in the words of the obituary in Voprosy istorii, the basic phenomena of socioeconomic, political, and cultural history of Kievan Rus' and seventeenthand eighteenth-century Russia, the most important theoretical aspects of the Leninist conception of the historical process, and many concrete phenomena of the historical reality of that time as well as the development of the class struggle of the masses in Russia from the eleventh to the eighteenth centuries, the history of social thought, and the economic and sociopolitical evolution of Russian medieval society and state.

Cherepnin is best known at home and abroad for his penetrating investigation of the structure of society and state in the period from the fourteenth to the seventeenth centuries and especially the formation of the centralized state. One can follow the sources, evolution, and fruits of these studies over several decades: in the 1920s the first papers at Moscow University and the Institute of History; in 1940 the appearance of a portion of his candidate's dissertation; in 1948 and 1951 the publication of his doctoral dissertation, Russian Feudal Archives of the Fourteenth and Fifteenth Centuries; in 1953 his substantial contributions to the major collective work, Essays on the History of the USSR, Period of Feudalism; in 1960 the major monograph, The Formation of the Russian Centralized State in the Fourteenth and Fifteenth Centuries, and connected studies of the 1950s and 1960s ; and, finally, in 1978 Land Assemblies of the Russian State in the Sixteenth 
and Seventeenth Centuries, with its series of preparatory articles in the 1960s and 1970s. To this body of work one can add, moreover, numerous byproducts in the areas of document publication and auxiliary historical disciplines. Indeed, no less than one-third of Cherepnin's scholarly writings was devoted to these two areas.

For Cherepnin, the most ambitious monograph could only be as meritorious as its author's approach to the sources from which it was constructed. He invariably stressed the "source methods, analysis, and synthesis inherent in any historical investigation," and frequently repeated his axiom that "the best monographs organically unite problems of source study and the historical construct." In Cherepnin's own creative experience, "the source analysis occupies the most important place in almost every work." 6 His greatest debt in the area of source study was to the methods of textual analysis developed by A. A. Shakhmatov or, in the words of his biographers, "in the creative transformation of Shakhmatov's methods." Cherepnin regarded the application of methods devised by Shakhmatov for the study of chronicles to public and juridical memorials as his principal scholarly achievement.

Soviet colleagues stress the historiographical importance of Cherepnin's doctoral dissertation. They find in it "the wellsprings of many of the most important theoretical and concrete directions of source study and a number of auxiliary historical disciplines," "the beginning in Soviet historical scholarship of contemporary diplomatics and, to a significant degree as well, source study of legislative memorials."

The innovative significance of this work consists in the fact that Cherepnin, supporting himself on the works of the founders of Marxism, worked out the principles of the scholarly analysis of the documentary [aktovoi] source as the monument of political class struggle. This permitted [him] to rethink critically the legacy of bourgeois source study, to transform its factological riches and methodological achievements in the service of Soviet scholarship. ${ }^{8}$

In his doctoral dissertation, Cherepnin suggested the principal stages in the development of the centralized state, a theme he brought to completion in his 1960 monograph. This enormous volume is said to provide the leading conception on the subject in Soviet historiography, the starting point for comparative historical investigations first with regard to the east of Europe and then all of Europe. Indeed, Cherepnin's entire corpus on the centralized state is compared in importance for Soviet historical scholarship to Grekov's work on the history of the old Russian state. ${ }^{9}$

Cherepnin regarded his last slender volume on land assemblies as the direct continuation of the two earlier monographs. The study developed the argument of the 1960 monograph that the initial form of political centralization in Russia was the estate-representative monarchy formed at the boundary between the fifteenth and sixteenth centuries. It reproduces the system of construction adopted

6. Pashuto and Nazarov, "Pamiati starshego druga," p. 149.

7. Ibid.

8. Obshchestvo, p. 5.

9. Ibid., p. 6. 
in the first part of Russian Feudal Archives. In his words, "the methodological paths of investigation in both books are analogous: from the source (and, where possible, from the archive preserving the source) to the fact and the historical phenomenon." The first task of the book is to set forth "the complete factual history of land assemblies," the second to work out a conception of the Russian estate-representative monarchy, and the third to initiate Soviet comparative historical study of Russian land assemblies and West European estate-representative institutions. ${ }^{10}$

At the end of his life, Cherepnin returned to the comparative method of his graduate training and early scholarship. While this method had been closed to him after the publication of his candidate's dissertation, in his view it clearly constituted a critical aspect of any serious historical investigation of the period of his primary interest. "Historical synthesis," he wrote in the introduction to his last book, "is impossible without comparative-historical characteristics." The brief publisher's statement at the beginning of the volume took note of Cherepnin's striving, characteristic of much of his work, to associate the evolution of Russian forms with those of Western Europe:

The work of L. V. Cherepnin has special scholarly and political meaning in connection with its political direction against conceptions of contemporary bourgeois scholarship which denies the presence in Russia of expressed traditions of estate representation [and] reduces its sociopolitical structure to despotism founded on brute force. ${ }^{11}$

Cherepnin's understanding of the scholar's responsibility to his public included the obligation to provide meticulously prepared editions of the primary source materials for his monographs. More than thirty documentary collections in Cherepnin's bibliography record his participation as compiler, organizer, senior editor, and editorial board member. Another dozen editions are in process of publication. Among the most noteworthy titles in this area are the Testaments and Treaties of the Grand and Appanage Princes, Fourteenth to Sixteenth Centuries (1950), Documents of Feudal Landholding and Economy of the Fourteenth to. Sixteenth Centuries (1951-61), Documents of the Socioeconomic History of Northeast Rus', Fourteenth to Beginning of the Sixteenth Century (3 vols., 195264), Memorials of Russian Law (vols. 3-5, 7; 1954-63), and, most recently, Documents of the Russian State, 1505-1526 (1975). These editions "contributed greatly to fixing the standards for publishing juridical and public documents, for determining the tasks and scope of archeography in the area of medieval studies."12

In the area of the auxiliary historical disciplines, Cherepnin published textbooks on metrology (1944), chronology (1944), and paleography (1946 and 1956). His unpublished papers include a text on numismatics and the typescript

10. L. V. Cherepnin, Zemskie sobory russkogo gosudarstva $v X V I-X V I I$ vv. (Moscow, 1978), pp. 3-4. One may note that the concept "estate-representative monarchy" long posed a dilemma for Soviet historians. As was remarked in an article coauthored by Cherepnin, the term was not used by either Lenin or Stalin (see $V I, 1949$, no. 11, p. 10).

11. L. V. Cherepnin, Zemskie sobory, p. 2.

12. Nazarov and Ianin, "K semidesiatiletiiu," p. 152. 
of one of his first academic courses on source study. Among the rich legacy of work devoted to various types of primary sources, one should mention especially the major study of Novgorod birchbark documents as a historical source (1969), wherein Cherepnin analyzes the entire birchbark collection as it relates to extant written sources of the eleventh to fifteenth centuries.

The importance of Cherepnin's contribution to the study of early Russian history guaranteed him a central place in the compilation of those significant general studies of Russian history which are collective products of Soviet scholarship. As author, organizer, and member of the editorial board, his name is associated with Essays on the History of the USSR, Period of Feudalism; World History; History of the USSR from Most Ancient Times to the Present (first series); two volumes in several editions of a university text on the history of the USSR ; History of the Moldavian SSR ; the first volume of History of Rumania; and History of the Peasantry of Medieval Europe (3 vols.). According to Cherepnin's biographers, such undertakings strengthened his conviction concerning the need to apply comparative historical methods to the study of both sources and individual institutions, especially estate-representative institutions and absolutism and, indeed, the historical process of the feudal epoch as a whole.

The participants in these complex generalizing tasks were quickly drawn to theoretical questions. A scholar of Cherepnin's formidable erudition could not long remain aloof from the fundamental all-union discussions that constituted watersheds in the evolution of Soviet historical study. Beginning with his role in preparing the unsigned collective article entitled "Basic Tasks in the Study of the History of the USSR of the Feudal Period" (Voprosy istorii, 1949, no. 11) and especially his contributions in 1951 and 1952 to the major periodization debate, Cherepnin took an active part in all theoretical discussions. He explored in articles the significance of the works of Marx and Engels (1969) and Lenin (1963, 1969) for Russian feudal historiography, periodization, and source study. ${ }^{13} \mathrm{He}$ criticized the premises and results of Western scholarship of Russia $(1954,1962)$. He composed periodic summaries of Soviet achievements in the study of feudalism and outlined the tasks for its further development (1967, 1973).

Training, preference, and party priorities disposed Cherepnin to approach theoretical questions by historiographical means. Among his numerous publications in this last principal area of his contribution, the field of historiography, one can mention the university course published as Russian Historiography to the Nineteenth Century (1957), his contribution to Essays on the History of Historical Science in the USSR (vols. 2, 3, 4; 1960, 1963, 1966), and a cycle of articles about individual historians-his contemporaries, reachers, and preRevolutionary predecessors. He directed, moreover, the re-publication of S. M. Solov'ev's Russian History (15 vols., 1959-66) and the editions of selected works by M. N. Pokrovskii (4 vols., 1965-67), B. D. Grekov (4 vols., 1957-60), and

13. Also see his "I. V. Stalin o russkom feodalizme," Moscow University, Uchenye zapiski, 156 (1952) : 3-18, not listed in the published bibliography. Early in 1953, the Presidium of the Academy directed that "the working out of the brilliant legacy of the great continuers of the work of Marx and Engels-V. I. Lenin and I. V. Stalin-as the theoretical bases of historical science" must occupy a central place in the work of the Institute of History (Vestnik, 1953, no. 4, p. 78). 
S. V. Bakhrushin (4 vols., 1952-59). Finally, in 1968, he published a monograph on the historical views contained in the classics of modern Russian literature.

It is appropriate to close this review of recent Soviet tributes to Academician Cherepnin with two representative statements which seek to convey the essence of his distinguished contribution to the development of Soviet historical scholarship. First, from the tribute by N. M. Druzhinin and V. T. Pashuto:

With the blossoming of fatherland historical science into the arena of international historiography there emerge outstanding scholars, armed with Marxist-Leninist methodology and filled with patriotic pathos, broadly erudite investigators who think in a party spirit-the creators of the Soviet representation of world history and the role in it of our homeland, its peoples and, first and foremost, the Russian people. Among these scholars a prominent place is occupied by L. V. Cherepnin: his works and his entire activity contributed much to the fact that the Soviet historiography of an entire epoch - the epoch of feudalism-both by its scientific method and mastery of sources has greatly exceeded the old classics of fatherland scholarship and their foreign adepts. ${ }^{14}$

Second, from the obituary by Pashuto and Nazarov:

The contribution of L. V. Cherepnin to historical scholarship is amazingly great. It is difficult to believe that this is the result of the activity not of a collective of highly qualified specialists but of only one man whose attachment to his calling was tested by life's severe trials, [whose] conditions of work in research were far from always optimal. . . . Lev Vladimirovich counted himself among those who "had been fortunate to observe the development of historical scholarship in the USSR almost from its first steps." Such a selfcharacterization is the fruit of modesty. L. V. Cherepnin did not "observe," but, in the full measure of the tremendous research gift granted him by nature, created this science-from the student bench to his very last days. ${ }^{15}$

iii

It is the nature of the obituary to emphasize the heights which its subject attained in life but to leave little place to explore the route by which he arrived. In the case of L. V. Cherepnin the route, spanning the first six decades of Soviet history, claims special interest for an American audience that has only recently begun serious study of the history of Soviet historiography. To follow this route is, of course, to appreciate the influences and pressures that shaped the intellect and the career. It is also to see, through the formation of a single historian, the tumultuous process by which his profession was re-created in the aftermath of revolution, and to witness in some small measure the emergence of the larger group to which he belonged, the Soviet intelligentsia. The following pages present a modest beginning to a more broadly contemplated study of the life and work of L. V. Cherepnin, a brief view of the landscape through which his route passed. They are written in memory of a distinguished scholar, who, while wielding his

14. Obshchestvo, p. 3 .

15. I SSSR, 1978, no. 1, p. 155. 
formidable prestige and authority in defense of Soviet scholarship against Western historians and critics, never ceased to value the connections between Russia and the West, Russian history and Western history, Soviet historians and Western historians.

L. V. Cherepnin was born in Riazan' in the revolutionary year 1905 (March 30/April 12). The previous year his father, Vladimir Alekseevich, had completed studies at the historical-philological faculty of Moscow University, where he worked with the prominent historian M. M. Bogoslovskii and formed close friendships, it is said, with future scholars of note-Iu. V. Got'e, S. K. Shambinago, and A. I. Iakovlev. Later, Vladimir Alekseevich took supplementary courses at the Petersburg Archeological Institute and the juridical faculty of Petersburg University. He worked as an archivist, apparently for a time at the Rumiantsev Museum in Moscow. The historical and archival interests of Cherepnin's father were fostered by the example of his grandfather, Aleksei Ivanovich, who, at the age of about forty, abandoned work as an agronomist to join the burgeoning activities of the Riazan' Archeographic Commission and to participate in local archeological excavations. Without specialized historical training, Aleksei Ivanovich emerged as a leading regional historian, archeologist, and numismatist (his most important work was published in Moscow ${ }^{16}$ ). He contributed to the flourishing of the Riazan' Scholarly Archival Commission, and for a time he served as curator of its Archeological Museum.

If, in their effort to establish the "democratic" allegiances of the family, Soviet biographers do not specify just which "repressions from tsarist authorities" were suffered by Cherepnin's father for his participation in student disturbances, they offer more details about his grandfather. Aleksei Ivanovich was expelled for composing "scandalous verse" about the administrators of the Riazan' gymnasium. He was expelled from Moscow University in the turbulent year 1861 for participating in the student movement and denied the right to reside in the capital cities for four years. He was involved later in the decade in student unrest at the Petrovsk Agricultural Academy. Details about the lives of Cherepnin's father and grandfather are brief, but Soviet colleagues stress a theme of unflagging devotion to learning and accomplishment despite "serious obstacles imposed by life." This theme is no less applicable to L. V. Cherepnin.

Cherepnin entered the Repman private classical gymnasium in Moscow and emerged in 1921 from the "labor" school into which it was converted after the Revolution. ${ }^{17} \mathrm{He}$ later recalled in taped reminiscences what much of his later professional work clearly demonstrates-the importance for his general cultural development and later studies of the training in three languages and the humanist education based on broad reading. ${ }^{18}$ His advanced education began in 1921, not in Moscow, but at the Riazan' Pedagogical Institute, one of the new higher schools (vuzy) staffed by former gymnasium teachers. Of more importance than formal

16. A. I. Cherepnin, "O grivennoi denezhnoi sisteme po drevnim kladam," Trudy Moskovskago numizmaticheskago obshchestva, vol. 2 (Moscow, 1901).

17. For an interesting account of the purposes and conditions of the radical experiment known as the "labor" school, which aspired to merge school "with life itself," see, among others, Dela $i$ dni, 1 (1920): 585-86.

18. The interview took place on June 1, 1972. The tape is deposited in the Sector of the History of the Most Ancient States, Institute of History of the USSR, Moscow. 
education, however, was the influence of N. G. Berezhkov, former employee of the Moscow Archives of the Ministry of Justice, who worked in the Riazan' provincial archives from 1920 to 1923 and later returned to Moscow, where he became an associate of the Institute of History and a leading specialist on the Lithuanian Metrika. Thanks to Berezhkov, Cherepnin supplemented his earlier reading of Solov'ev, Kliuchevskii, and Platonov with Pavlov-Silvanskii, Presniakov, and Shakhmatov, that is, with historians whose themes in the case of the first two, and whose methods in the case of the third, would dominate Cherepnin's mature scholarly work. He resolved to enter the university.

He attended what was in those days the three-year course at Moscow University as an auditor (fakul'tativno), living in evident hardship and tutoring to make ends meet. He came to the university in the year "alien class elements" were purged from student ranks to accommodate a large influx of soldiers, workers, and peasants. In this colorful and undisciplined milieu, the student could hear the lectures of established professors as well as the new luminaries M. N. Pokrovskii and A. V. Lunacharskii. In 1919, the historical-philological faculty, like the juridical, was replaced by the faculty of social sciences, as the new government strove to undermine quickly the bulwarks of pre-Revolutionary historical scholarship. ${ }^{19}$ This bold experiment, designed to introduce and place the teaching of the social sciences on a firm Marxist basis, soon foundered for many reasons. Not the least of these were the difficulties of staffing the new, required "shock courses" with qualified Marxist teachers, the problems of satisfactorily interpreting vast quantities of new materials and quickly providing acceptable teaching tools, the disruptions caused by commissions of students, teachers, and representatives of "public organizations" constituted in order to monitor the content and methods of teaching, and the consequences which attended the strenuous activity, especially in 1923, of the student party organization in the larger political arena. ${ }^{20}$ Starting with the 1924/25 academic year, it was decided to phase out the faculties of social sciences in the course of two years. For those who had passed through them, the quality of education in these years could only have been eroded by the conditions of a turbulent environment and an extreme material want. For future historians in particular, the absence in these years of systematic and integrated historical studies and the new emphasis on particular aspects of the modern period to the exclusion of ancient and medieval history could only affect adversely, as one Soviet commentator has remarked, not only the acquisition of factual knowledge but the assimilation of Marxist theory and methodology as well. ${ }^{21}$

Cherepnin pursued his studies at the university with distinguished specialists in European medieval and early Russian history, with D. M. Petrushevskii and

19. The following brief account of Moscow University at this period is based on the informative work, well grounded in archival research, by L. V. Ivanova, $U$ istokov sovetskoi istoricheskoi nauki (Podgotovka kadrov istorikov-marksistov v 1917-1929 gg.) (Moscow, 1968), part 1, chapter 1, pp. 10-35.

20. Ivanova writes of the supporters of Trotsky in the party organization of MGU, the activities in 1923 of the Left S.R.'s, the broad struggle of the party with Trotskyism from autumn 1923, the reorganization in 1924 of party cells in higher schools, and the first mass "inspection" of cell membership in the higher schools in May 1924, as a result of which fifteen percent of students was expelled for academic and political reasons (ibid., pp. 33-34).

21. Ibid., p. 31 . 
D. N. Egorev, S. V. Bakhrushin and A. I. Iakovlev. The most fruitful experience would appear to have come from seminars, a number of which later yielded publications. At Cherepnin's funeral in 1977 it was recalled that at just this period, October 1924, he first arrived at the Moscow Central Historical Archive (the present TsGADA) on the recommendation of Professor Iakovlev to pursue in the documents of the Razriadnyi prikaz the theme "The Struggle of the Peasantry against Gentry Authority in the Seventeenth Century." The choice was an indication of the extent to which research interests at the university were being adapted to the new priorities. His reader's card, used for the next half-century, bore the number 2 of what is today over eight and one-half thousand registered scholars.

In the fall of 1925, Cherepnin passed the entrance examination for the Institute of History. One of a series of scientific research establishments, the institute was founded at the beginning of the decade on the initiative mainly of professors at Moscow University. ${ }^{22}$ It had recently been transferred from the jurisdiction of the Faculty of Social Sciences of Moscow University to the new Russian Association of Social Sciences Institutes (RANION) under direct control of the Commissariat of Education. This, the most recent of several reorganizational efforts, pursued the stubbornly elusive goal of reconciling the professoriate's insistence on the principle of autonomy in the selection of faculty and students and in the administration of institute affairs with the government's commitment to effective guidance and control of "commanding positions" by party scholars. Indeed, owing to the extreme shortage of qualified party scholars, the entire graduate training in the social sciences would be concentrated in Moscow. The Institute of History thus became the most important locus of professional preparation apart from the Institute of Red Professors and the Communist Academy.

Cherepnin's application auspiciously coincided with what was deemed a year of turning (perelomnyi god) in the content, method, scope, control, and indeed the very system of graduate training. An inability to deliver properly trained Marxist cadres in sufficient numbers to accommodate the greatly expanding system of higher schools provoked extreme dissatisfaction, aired during 1924 and 1925 on the pages of Pravda, and made reform of higher education a "shock task." On June 30, 1925, the Commissariat of Education inaugurated the graduate program of aspirantura. For the first and last time in the brief existence of RANION, a broad, planned recruitment was implemented in the fall of 1925 which increased the numbers enrolled in all research institutes of RANION from seventy-nine to two hundred ninety and in the Institute of History from fifteen to thirty-seven. (In the very next year statistics suggest a return at the institute to preferential selection of party candidates.)

The composition of the RANION selection commission accentuates the importance attached to the new program's objectives. It was composed of representatives from the party's Central Committee, the presidium of RANION, the institute, and the party cell therein who employed

22. The background of Cherepnin's years which appears in the next paragraphs draws again from ibid., part 2, chapter 1, pp. 84-121. See especially Professor M. M. Bogoslovskii's draft "Ustav istoricheskogo instituta," described on p. 89. 
as the criterion of selection, along with the results of tests (in particular the evaluation of written work and tests on Marxist theory and methodology), the candidate's general steadfast adherence [vyderzhannost'] to Marxist ideology . . . as well as the aggregate of data that could characterize the candidate from the sociopolitical side. ${ }^{23}$

"While paying principal attention to theoretical preparation (the examination on Marxism was obligatory for all), the commission also took into account the level of historical knowledge."24 Cherepnin, who submitted as evidence of scholarly competence his diploma essay on the class struggle of the peasants in southern Russia in the second half of the seventeenth century, enrolled in the institute in January 1926. There he encountered the distinguished Moscow University professors D. M. Petrushevskii and M. M. Bogoslovskii, as well as S. V. Bakhrushin, Iu. V. Got'e, and A. I. Iakovlev, several of whom, coincidentally, were known to his father before him.

The commissariat's "Instruction on Graduate Work in Scientific-Research Institutes of the Social Sciences" (1925) prescribed a program combining thorough study of Marxist theory and methodology with concentrated investigation of a given scholarly problem and study of two foreign languages. Persistent efforts were made in both theoretical and academic courses to foreclose the potentially deleterious effects of a staff dominated in the main by nonparty historians; methods were urged to undermine the replication of the "scholar-loner" (uchenyiodinochka) by requiring broader faculty participation in the formulation of individual study plans and dissertation proposals, and, in the particularly sensitive area of ideological preparation, by establishing minimum requirements and adopting in place of individual work or lectures the seminar format pioneered at the Institute of Red Professors. ${ }^{25}$

Perhaps no single source better conveys the broad dimensions and enthusiastic perspectives of the institute's work in this period than the detailed published report for the academic year 1926/27. ${ }^{26}$ For example, the sector on medieval history, headed by Petrushevskii, proposed to join the vigorous international debate on questions of feudalism, among them

the elucidation of the essence of feudalism by means of concrete study of its various forms and analysis of the very concept "feudalism". . . . In view of the fact that in contemporary historical science (as a result of the works of Zelinger, Caro, Dopsch ...) there is taking place an animated review of all [these] questions, the section of medieval history has posited as its task the participation in this review insofar as it is able. ${ }^{27}$

Cherepnin's chosen dissertation topic, "The Feudal Votchina of the Fourteenth to Sixteenth Centuries," while relating to this general debate, would more directly fuel the crucial discussion which engaged Soviet historians and theoreticians in the 1920s: how to define Russian historical experience in a comparative

23. Protocol of the Presidium of RANION, August 25, 1926, quoted in ibid., p. 97.

24. Ivanova's quote in ibid.

25. On efforts to improve the program and the difficulties, see ibid., pp. 102-103, 109.

26. RANION, Institut istorii, Uchenye zapiski, 7 (1928).

27. Ibid., p. 155 . 
European perspective that was properly grounded in Marxist theory. The topic, it is said, ${ }^{28}$ proved so complicated with regard to both theory and sources that Cherepnin was assigned two advisers-Bakhrushin and Iakovlev. His methodological approach was said to depend on the advice of the Marxist historians V. I. Volgin, V. I. Nevskii, M. N. Pokrovskii, and A. D. Udal'tsov, who were attached to the institute in a consultative (neshtatnyi) capacity.

The 1926/27 report does not mention Cherepnin's dissertation specifically, but it does associate him with the continuing work of Iakovlev and S. B. Veselovskii who were exploring the voluminous records of the Trinity Monastery's vast landholding in the sixteenth and seventeenth centuries. (One summer Cherepnin shared a monastic cell with Veselovskii and copied out documents from six A.M. to three P.M. each day.) The annual report also records Cherepnin's delivery of a methodological paper on the sources and redactions of the "New Chronicle" (Novyi letopisets), a continuation of an earlier university seminar, and his service as secretary of the institute's bibliographical commission. Of special interest as an indication of the variety of approaches taken at the institute in that period, it mentions that beyond his planned work he prepared for publication an article entitled "Witchcraft and Black Magic in the Seventeenth Century," which appeared under a revised title in the institute's journal in 1929. This work, the product of a seminar with P. F. Preobrazhenskii, "On the History of the Relations of Backward [malokul'turnye] Peoples," presents descriptive material gleaned from published and archival materials in the context of conceptual and classificatory premises formulated in the recent writings of American and European scholars like Frazier, Hubert and Mauss, Vierkandt, Lowie, Goldenweiser. It also suggests familiarity with the work of Durkheim and Levy-Brühl.

While subsequent volumes of the institute's Uchenye zapiski no longer provide the detail of the 1926/27 report, nevertheless one can trace the direction of Cherepnin's training, firmly rooted in the critical use of major primary sources. ${ }^{29}$ He studied the "Capitulare de villis" with Professor Petrushevskii and collaborated in producing major documentary publications-with Iakovlev the edition of Russkaia Pravda (1928) and with Veselovskii and Iakovlev Memorials of the Socioeconomic History of the Moscow State, Fourteenth to Seventeenth Centuries, vol. 1 (1929). In 1928, he published his first modest and somewhat diffuse article, "On the History of the Struggle for Peasants in the Moscow State at the Beginning of the Seventeenth Century," a work based largely on an attempted classification and analysis of documents from the Trinity Monastery archives in combination with other published and unpublished sources, in order to elucidate the patterns of monastic peasant movement during the Time of Troubles. It is known also that as required pedagogical practice he conducted seminar work at the ethnology faculty of Moscow University. ${ }^{30}$ With the exception of his two published articles, the results of scholarly work commenced at the university and the institute- on the "Charter of Pskov," the chronicle of Prince Daniil of Galich, the "New Chronicler," the "Capitulare de villis"-were to appear years

28. $V I, 1975$, no. 5 , pp. $149-50$.

29. See the list of Cherepnin's reports in Ivanova, $U$ istokov sovetskoi istoricheskoi nauki, p. 107. The last was given on January 31, 1927.

30. Ibid., p. 110. 
later. At the end of the 1920 s came a major crisis, a turning point in the professional and personal lives of Cherepnin, his fellow students, and many of his teachers.

The "cultural revolution" that accompanied the First Five-Year Plan, with its class war against hostile social elements, ${ }^{31}$ shattered the gradually eroding immunity of the Institute of History no less than countless other establishments, large and small. In 1929, RANION was dissolved and all institutes transferred to the Communist Academy directed by Pokrovskii. Warning signals had flared in the institute's last years: the erratic publication schedule of the institute's journal, ${ }^{32}$ periodic efforts to reinforce the Marxist nucleus in the RANION presidium and institute collegia, frequent tinkering with mechanisms for improving the sharply criticized ideological preparation and control of students and faculty, the expulsion of almost 10 percent of RANION graduate students during the "inspection" (proverka) of 1928, the unrelieved nonfulfillment of the three-year term for graduating cadres, the inevitable reference to inadequacies in resolutions of the party's Central Committee and the Commissariat of Education. ${ }^{33}$ All of these events confirm the fierce tensions that plagued earnest efforts at the Institute of History to employ "non-Communist hands in the building of communism."

Pokrovskii's address at the opening of the Institute of History of the Communist Academy on November 18, 1929, gives vent to frustration and exasperation:

When we saw that they are beginning to prepare for us graduate students according to the recipe of 1910 , then even we, unusually patient people, . . . finally lost patience and said: What will come later? What will we do with these young people prepared on the model of 1910 ? . . What will they do? ... The way out was the decision to transfer the Institute of History from RANION to the system of the Communist Academy so that in the first place it would fall into a Marxist environment, into a purely Marxist atmosphere and in the second place that in the process it would divest itself of those elements which are absolutely unsuited to any use in Soviet conditions, preserving only those scholarly workers who, one way or another, can also be used in the Communist Academy where, as you know, there are enough nonparty workers from other staffs. ${ }^{34}$

A radical excision of personnel accompanied the transfer. Academician Petrushevskii and a number of scholars, including Bakhrushin and Got'e, were sent away, some to perish, others to survive "reforging" in camp or exile. Of Cherepnin's mentors it would appear that only Iakovlev, named Corresponding Member of the Academy in 1929, was spared arrest, perhaps owing to personal

31. Cf., for example, Pravda, June 8, 1928.

32. It appeared out of chronological sequence: volume 1 in 1926 ; volume 2 in 1927 ; volume 3, which includes the annual report for $1924-25$, in 1929 ; volume 4, which includes only materials relating to Russia, in 1929; volume 5 in 1922; volume 6 in 1928; and volume 7 in 1928. From volume 7, p. 166, it is seen that volumes 3 and 4 were given to the press in 1926-27 (Uchenye zapiski, 7 [1928]: 166). On volume 5, see $V I, 1950$, no. 3, p. 156.

33. Ivanova, $U$ istokov sovetskoi istoricheskoi nauki, pp. 110-12, 118.

34. Istorik-marksist, 1929, no. 14, p. 6, cited in ibid., p. 119. The new Institute of History opened with a staff of forty and thirty-six graduate students. 
connections with the Ul'ianov family in Simbirsk. ${ }^{35}$ Of Cherepnin himself, we know only that, after leaving the institute formally on October 1, 1929, he worked briefly at the manuscript division of the Lenin State Library in Moscow (the former Rumiantsev Museum). The personal details of his life in the 1930s are, for the most part, passed over in silence by his biographers or with spare reference to the "harsh experiences of life."

According to the memoirs of another historian, N. M. Druzhinin, certain associates and graduate students of RANION were compelled to "switch over" to the history of technology, others to work as statisticians, a third group to quit Moscow altogether ${ }^{36}$ Careful reading about Cherepnin's life and work suggests that, like his grandfather before him, he was denied the right to reside in Moscow, with all attendant material and mental hardship, to return legally only during World War II. Where he went and under what circumstances are not known. ${ }^{37}$ One notes the reference in his bibliography to a popular article published in spring 1937 in the Pioneer (Kursk). The reluctance of Soviet colleagues to speak of these years is all the more regrettable, because it may be said to diminish the heroic fact of survival, the extraordinary combination of will, tenacity, and good fortune that enabled some of the talented to return to the profession. In any case, one may speculate that Cherepnin's ability to withstand the blow and to sustain himself as a scholar depended on the support of loyal colleagues and teachers, both those spared and those who managed to return after 1934.

iv

The elaborate debate on socioeconomic formations which occupied prominent Marxist historians at the close of the 1920s yielded a new theoretical synthesis that ambitious, detailed research into discrete problems was intended to reinforce and refine. ${ }^{38}$ For the study of the feudal formation and, more narrowly, its Russian variant, the discussion may be said to have begun with the much publicized attack on D. M. Petrushevskii's Essays on the Economic History of Medieval Europe (Moscow, 1928). ${ }^{39}$ It moved beyond Pavlov-Silvanskii and his recent commentators to focus, from the beginning of the $1930 \mathrm{~s}$, on the problem of serf183.

35. [L. V. Cherepnin], "Aleksei Ivanovich Iakovlev (1878-1951)," VI, 1951, no. 9, p.

36. N. M. Druzhinin, Vospominaniia i mysli istorika (Moscow, 1967), p. 45.

37. The annual of the $B S E$ on the occasion of Cherepnin's elevation to the rank of academician, offers the phrase: "In 1929-35-in historical-archival and literary work" (Bol'shaia sovetskaia entsiklopediia, vol. 17 [Moscow, 1973], p. 632).

38. L. V. Danilova strongly defends the argument that this discussion, together with parallel discussions in philosophy and sociology, had exceptional significance for the development of Marxist historical thought and marked the victory of the Marxist direction in all branches of Soviet historical scholarship (see L. V. Danilova, "Stanovlenie marksistskogo napravleniia $\mathrm{v}$ sovetskoi istoriografii epokhi feodalizma" (hereafter cited as "Stanovlenie"), in Istoricheskie zapiski, 76 (1965): 62-119 (hereafter cited as IZ). Following the discussion on socioeconomic formations, plans were made for broad synthetic and monographic investigations of the feudal period in order to provide "a concrete picture of feudal society on the territory of the Union and its genesis, functioning, and transition to a higher form" (for details, see Danilova, "Stanovlenie," p. 118).

39. Istorik-marksist, 1928, no. 8, pp. 79-128. One crucial aspect of the discussion concerned Petrushevskii's relation to the work of Max Weber. 
dom and the barshchina economy. ${ }^{40}$ Scarcely confined to the Academy, however, the discussion was contaminated by the association of difference with disloyalty and, in some cases, with treason. Those historians dispersed in the reorganization of academic institutes and journals could not suspect that, within a few years, the survivors would be summoned to return, not merely on sufferance, but as leaders of an even more profound reorganization of the entire educational system, an accompaniment to the consolidation of Stalin's personal dictatorship. Nor could they predict that they would be implicated, however indirectly and unintentionally, in the attendant decimation of the ranks of their recent accusers, the leading Marxist historians and the latter's students, who had been so carefully nurtured in the new, ideologically oriented higher schools during the previous decade.

The "revolution on the historical front," announced by the decree of May 16,1934 , on the teaching of history in the schools, drew the newly reconstituted discipline back to principles expounded in an earlier period-chronological sequence, factual memory, traditional periodization-each judged essential to ensure "comprehensibility, clarity, and concreteness." History departments were restored in the universities, the doctoral degree was instituted, and the Institute of History was placed directly under the Academy of Sciences. The process, while discrediting and removing the very forces mobilized in previous years for the struggle with bourgeois historiography, brought B. D. Grekov to professional leadership in place of M. N. Pokrovskii and returned to their former posts at the Institute of History a number of Cherepnin's former teachers, among them Petrushevskii, Bogoslovskii, Bakhrushin, Iakovlev, and Veselovskii.

One might have expected at this juncture that Cherepnin too would be permitted to resume his interrupted term at the institute. That such an eventuality was being prepared is suggested by the appearance in 1934 of his seminar work with Petrushevskii, "On the question of the composition and origin of the "Capitulare de villis," " in the prestigious Izvestiia of the Academy of Sciences in Leningrad. Curiously, this article is the only piece ever published in the journal to be sponsored by the "editorial nucleus" (redaktsionnaia iacheika) rather than the customary academician or institute. ${ }^{41}$ The work, which meets the highest scholarly standards, argues on the basis of close analysis of the Latin text the proposition that the "Capitulare de villis" should be understood as an ordinance first issued by Charlemagne's officials for Aquitaine and then transferred to northern France and joined with two sets of regulations issued by the king for his own estates. ${ }^{\mathbf{4}}$ Cherepnin's careful criticism of the French and German monographic literature is rooted entirely in the textual analysis.

If the dramatic reorientation on the historical front did not allow Cherepnin to rejoin the staff at the Institute of History at this point, as it did other more prominent scholars of the older generation, it rendered more acceptable and potentially useful the basic elements of his historical training. It provided him at least a

40. Danilova, "Stanovlenie," p. 107.

41. Izvestiia $A N$ SSSR. Otdel obshchestvennykh nauk, no. 5, pp. 359-86. In accordance with the new charter of the Academy in 1930 (article 58), a new editorial-publications council was established, chaired by the permanent secretary, who controlled academic publications (Sobranie zakonov $i$ rasporiazhenii $S S S R, 1930$, no. 30). The post was held from early 1930 to 1935 by V. P. Volgin, a Marxist historian, former president of Moscow University, and one of the founders of the Institute of Red Professors. Note that he was named as one of Cherepnin's advisers in preparing the candidate's dissertation.

42. Izvestiia $A N S S S R$, p. 376. 
modest connection to the group in the form of a contract in 1935 to work on the recently commissioned multivolume history of the multinational state.

The party placed before the Institute of History two principal tasks in the mid-1930s. The first task was to demolish the Pokrovskii school, that is, to undertake the wholesale repudiation of Marxist post-Revolutionary scholarship. The several volumes denouncing Pokrovskii (1939 and 1940) and the anniversary volume Twenty-five Years of Soviet Historical Scholarship (1942) amply indicate the magnitude of the dilemmas occasioned by the attack on what A. Pankratova, a former zealous student of Pokrovskii, now labeled "naked, schematic, sterile sociology, inimical to Marxism-Leninism."43 The second task was to compose major synthetic historical works, simultaneously general and specific, that would provide a "harmonious Marxist-Leninist conception of the entire course of our history." 44 B. D. Grekov, who assumed major responsibility for this undertaking, suggests its dimensions:

It was necessary to depict the history of the multinational state so that each people which has entered the Union would find its place in the history of the USSR and just that place which corresponds to its own history as well as to its participation in the general political life of Russia and later also the USSR.45

The magnitude and urgency of the assignment dictated the use of collective forms of work Only well-coordinated efforts of large groups could meet the requirements of preparing at one and the same time documentary collections, textbooks, and general syntheses, especially with reference to minority peoples whose history in many cases was virtually unknown. Even more difficult was agreement on a satisfactory periodization, a defensible approach, and a stable underlying conception. If joint responsibility maximized the utilization of party and nonparty resources, it would also shelter in relative anonymity the missteps of those whose theoretical training lacked the distinction of their academic training and shield able younger scholars like Cherepnin who had much to offer in this work. Moreover, it could weld the closest bonds among hard-pressed scholars who, denied adequate resources and clear guidance, were frequently obliged to defend themselves against charges of deliberate delays, preference for documentary publications over generalizing works, and later of egregious errors, the consequences of which were only too evident at the time.

Cherepnin could not have sustained the burdens of these years, worked constructively in his discipline, and prepared unobtrusively his return to a regular position in 1942, without the help of devoted and well-placed colleagues. Among these, two appear to be of particular importance: A. I. Iakovlev, family friend and former teacher, who resumed his post at the institute in 1938; and Academician B. D. Grekov, authoritative scholar, editor, and organizer, who became director of the Institute of History in 1939 and the moving force behind its collective under-

43. A. Pankratova, "Razvitie istoricheskikh vzgliadov M. N. Pokrovskogo," in Protiv istoricheskoi kontseptsii M. N. Pokrovskogo: Sbornik statei, vol, 1 (Moscow-Leningrad, 1939), p. 7.

44. Druzhinin, Vospominaniia, p. 50.

45. B. D. Grekov, "Osnovnye itogi izucheniia istorii SSSR za dvadtsat' piat' let," in Dvadtsat' piat' let istoricheskoi nauki v SSSR (Moscow, 1942), p. 88. 
takings. ${ }^{46}$ No scholarly publication by Cherepnin in this period fails to suggest, directly or indirectly, the support and collaboration of one or the other. In 1939-40, Iakovlev's project on the history of the Mordva produced three volumes entitled Documents and Materials on the History of the Mordovian ASSR (vol. 3, part 1 [Saransk, 1939] ; vols. 1-2 [Saransk, 1940]). His editorial credits were shared with Grekov, V. I. Lebedev, and Cherepnin. ${ }^{47}$ In 1940, Iakovlev and Cherepnin jointly issued a translation and commentary on the Pskov Charter, work begun in Iakovlev's seminar over a decade before. In 1941, Cherepnin issued Materials for a Bibliography on the History of the Mordovian People, clearly a cooperative effort with Iakovlev. ${ }^{48}$ Cherepnin contributed over a dozen unsigned pages on the Volga peoples in the second half of the nineteenth century to Istoriia SSSR, vol. 2, edited by M. V. Nechkina (Moscow, 1940). He placed three articles in 1938, 1940, and 1941 in the new journal Istoricheskie zapiski, edited by Grekov, the second of which was a synopsis of his candidate's dissertation prepared in the 1920s. This series of publications, if joined to the successful defense of his candidate's dissertation, would have qualified Cherepnin for the doctoral program established in 1934.

The first article in Istoricheskie zapiski, "Class Struggle in 1682 in the South of the Muscovite State," recalls university work begun with Iakovlev in the archives of the Razriadnyi prikaz. ${ }^{49}$ It introduces the strel'tsy rising in May 1682 as one link in the developing class struggle against serfdom and dismisses its participants as a reactionary force refusing to ally with peasant rebels and capitulating to the government. The more substantial parts of the article extend the confines of the title. One such section, chronicling the vacillations in government decrees after the 1649 code, demonstrates the tension between the state's decision to buttress the declining economic and service position of the gentry in central provinces by supporting the return of runaway serfs and the state's need to maintain in border regions an effective defense force recruited heavily from runaway serfs. This inability to define a consistent policy undermined the firm establishment of serfdom before the century's close. The second half of the article relates three episodes of southern turmoil and concerns particularly the plight of Cossacks whose livelihood had been jeopardized by the Turkish treaty on the eve of the uprising; it concludes with echoes of the rebellion among strel'tsy regiments stationed in the south. The stated analytical framework, unsupported by theoretical citations, would have benefited from a more thorough integration of the archival evidence presented. Characteristic of the work are the author's

46. On Grekov as the "soul" of the new Institute of History, see Druzhinin, Vospominaniia, p. 56. The obituary in Voprosy istorii introduces Grekov as the closest student of Petrushevskii and concludes: "His authoritative word, the word of the most prominent Soviet historian-Marxist, resounded everywhere that scholarly historical problems were posed and resolved" (see VI, 1953, no. 9, pp. 164-67).

47. Volume 1, part 2 appeared only in 1950, edited by Iakovlev alone, as was volume 3, part 2, published in 1952.

48. Grekov lists these volumes among the most valuable documentary publications on the history of the peoples of the USSR (Grekov, "Osnovnye itogi," p. 79). Cherepnin's published bibliography omits lakovlev's name in its listing, but the introduction to the reissued work in 1975 mentions their collaboration.

49. L. V. Cherepnin, "Klassovaia bor'ba v 1682 g. na iuge Moskovskogo gosudarstva," IZ, 4 (1938): 41-75. 
respect for complexity and detail, his attention to the intricacies of juridical formulae, and, most striking, his desire to let the documents themselves speak.

The third article in Istoricheskie zapiski treats the chronicle commissioned by Daniil of Galich, the major source on western Rus' of the thirteenth century, and appears under the rubric "Questions of Source Study."50 It reshapes the textual analysis begun in Bakhrushin's university seminar in a patriotic spirit. Here Daniil's struggle against his boyars is presented as a "progressive phenomenon," given their alleged intention, with the help of Hungarian kings and Polish princes, to advance "grasping plans against Rus'." Concerned with stylistic and ideological influences on source composition, Cherepnin connects the text to other literary memorials of the time, including the "Tale of Igor's Campaign," to propose the existence of an important Galician-Volynian literary school "dedicated to struggle with foreign usurpers and traitors to the motherland."

The second article in Istoricheskie zapiski, an excerpt from Cherepnin's candidate's dissertation, merits more extended review. It may be seen as his first serious effort-haltingly undertaken and inadequately executed-to construct a bridge between present requirements and past studies. While in the short term the effort directly affected his prospects for return to a productive professional life, in the long term it was to become the central focus of his striving and achievement. To the utmost of his energies and abilities, Cherepnin would seek to construct a bridge between a pre-Revolutionary tradition that stressed the study of juridical norms and institutions by means of the accumulation and classification of an ever-larger body of documentary evidence and its critical analysis, and the Soviet direction which stressed the elaboration and molding of the theoretical and ideological framework within which that documentary legacy could be acceptably viewed. This work thus constitutes a revealing point of passage, one which vividly betrays the enormity of the task and scarcely hints at the rewards inherent in its satisfactory resolution.

Modestly titled "From the History of Early Russian Feudal Relations of the Fourteenth to Sixteenth Centuries," the published version of Cherepnin's candidate's dissertation, which would appear to be markedly reduced and altered from the original, ${ }^{51}$ bears the strong imprint of the scholarly debate of the $1920 \mathrm{~s}$. This earlier debate, building on the legacy of Pavlov-Silvanskii, sought to demonstrate in the Russian past, and especially in the appanage period, the coincidence of essential attributes and institutions of Western feudalism. Cherepnin agreed with Pavlov-Silvanskii that to deny this proposition only betrayed ignorance of Russian sources and a defective knowledge of Western feudalism confined to general schematic traits. ${ }^{32}$ The principal purpose of Cherepnin's work would

50. L. V. Cherepnin, "Letopisets Daniila Galitskogo," $I Z, 12$ (1941) : 228-53.

51. L. V. Cherepnin, "Iz istorii drevnerusskikh feodal'nykh otnoshenii XIV-XVI vv.," $I Z, 9$ (1940): 31-80. All the remarks of Nazarov and Ianin (VI, 1975, no. 5, p. 150) and Pashuto and Nazarov (I SSSR, 1978, no. 1, p. 147) regarding the content and particularly the innovative character of the source work and theory contained in the dissertation do not seem to relate to the printed text.

52. For a convenient summary of N. P. Pavlov-Silvanskii's views, see Feodalizm v drevnei Rusi, 2nd ed. (Moscow-Petrograd, 1923). For criticism of some of his opponents, see pp. 45, 50. In Cherepnin's article ("Iz istorii"), the importance of Pavlov-Silvanskii and the 1920 s debate may be seen on pp. 40, 54,61, 66. Cherepnin also refers to the Veselovskii-Presniakov dispute on the origin of immunities (ibid., p. 75). 
appear to have been to extend Pavlov-Silvanskii's analysis by studying the late sixteenth-century compendia of documents preserved by the metropolitan see, primarily charters and treaties, which the author regarded as entirely analogous to the medieval church chartularies of Western Europe. ${ }^{\text {s3 }}$

Assuming the reader's familiarity with the content of Western feudal forms, Cherepnin used Western analytical categories and terms in six of eight subchapters to locate in metropolitan documents of the fourteenth to sixteenth centuries the essential elements of French (and, to a lesser extent, English) experience. Comparing Russian sources with selected Merovingian and early Capetian documents, he claimed to discover in the metropolitan documents prekarii and benefitsii (section 2), kommendatsiia of allody (section 3), vassilitet (section 4), zakladnichestvo-patronat (commendation of monasteries) (section 5), zakladnichestvo of artisan communities (section 6), and the feudal hierarchy (section 7) "which yielded immunitet, the crown of a feudal edifice composed of different forms of land-service relations embodied in the precarium, the benefice, and vassalage." Like Pavlov-Silvanskii, he vigorously opposed the thesis of Russia's distinctive development and judged specious the grounds often used to argue it --the mobility of the peasantry and serving princes. ${ }^{54}$

Onto this central and apparently original core of the dissertation there is grafted an introductory section which acknowledged, with cautiously quoted references, the main debate's shift in the 1930s from the consideration of feudalism as a juridical-political process to its consideration as a socioeconomic process, that is, to production relations as the essence of feudalism. These opening remarks, together with the first subsection, "The System of Domination and Subordination in the Feudal Village," suggest a very different intended direction from that actually taken, a circumstance affected in part at least by the fact that the extant sources, mainly juridical and political, are more suited to define relations among the elite than to analyze the exploitation of direct producers by means of noneconomic compulsion. Indeed, the scanty and conflicting evidence leads Cherepnin to conclude here and elsewhere in the article that thorny problems concerned with production relations "can be resolved, and I think best, with the aid of certain data from West European medieval feudal practice." 55 With due respect for the effort involved, this section proves the least successful part of the work. It lacks the coherence that would accompany mature understanding of the theoretical principles in which it is purportedly grounded, and lacks the strength that would derive from a more satisfactory source base and methodological approach. This section in any case is not well integrated with the core of the work. The same may be said of the last section, "The Feudal State," which no longer employs the metropolitan sources.

53. Cherepnin, "Iz istorii," p. 31. It is instructive to compare Cherepnin's analysis of the metropolitan documents with that of S. B. Veselovskii in Feodal'noe zemlevladenie $v$ severo-vostochnoi Rusi, vol. 1 (Moscow-Leningrad, 1947), part 2. See also Cherepnin, Russkie feodal'nye arkhivy $X I V-X V$ vekov, part 2 (Moscow, 1951) (hereafter cited as $R F A$ ).

54. Cherepnin makes the argument against the distinctiveness of Russian development in "Iz istorii," p. 50. On mobility, see Cherepnin, ibid., pp. 57 ff., and Pavlov-Silvanskii, Feodalizm, pp. 81-86.

55. Cherepnin, "Iz istorii," p. 32; see also p. 38 and the last section. 
In the last section Cherepnin criticizes bourgeois historiography for according undue attention to the fragmentation of sovereignty in the definition of the feudal state and for ignoring completely "the state feudal organization as a hierarchy of armed landlords, collectively dominating the direct producer by means of noneconomic compulsion." "56 In light of this definition, he continues, one should explore the most valuable source on state structure in northeast Rus' in the fourteenth and fifteenth centuries - the testamentary and treaty charters of the grand and appanage princes. Acutely sensitive to the limits and contradictions of Russian sources, he makes the same argument regarding the study of the state as he made earlier in the article regarding the study of serfdom, that is, that these sources cannot yield the most valuable results in isolation from analogous documents of the Western Middle Ages and from other types of sources, particularly early Russian and Western chronicles. Here, however, he uses only Russian charters to characterize the mutual relations among princely heirs which are founded at the time of partition on principles of subordination to the senior brother and the act of commendation of vassals. In this connection, he compares Russian princely testaments and treaties with the partitions of Pypin in 768 and the Carolingians in 807 and 817.

Cherepnin closes the article with what he considers characteristic of Marx's definition of the feudal formation- " 'the hierarchical structure of landed property and the related system of armed warbands' as bases of class domination of feudal lords over the direct producer in the person of the enserfed peasantry." Bourgeois scholars, he contends, speak about the "closed hierarchy of warrior shields," which "reflect the actual ladder of feudal relations," and about the "system of estate-hierarchical votchina organization of the armed forces of the country," but they have never been able to understand "the very deep secret, the innermost basis of the entire social structure'-the relation of the owner of the means of production to the direct producer." 57

The published version of the dissertation does not significantly advance the debate on larger theoretical questions of the definition of feudalism, its chronology in Russia, or its relation to serfdom. It does offer two possible directions for further fruitful research: the first emphasizes the economic side of the problem, the study of serfdom; the second, the political side, the study of the state structure. Either study, he maintains, should be grounded in comparative use of Russian and Western sources. Cherepnin chose the second, and he began, more narrowly, with the fundamental study of the Russian source base on which serious analysis of the state form must ultimately rest. In the 1930s, the formation of the Russian state drew increasing attention as a cardinal and neglected theme of historical research. It was placed high on the agenda proposed by Pankratova in 1942.58 Cherepnin would approach this formidable task through an exhaustive examination of major components of the Muscovite state archives, mainly the princely testaments and treaties. He would confine his examination to Russian sources, however, eschewing the Western comparison he had recently judged so essential to resolve the contradictions of Russian sources.

56. Ibid., p. 76.

57. Ibid., p. 80 .

58. A. M. Pankratova, "Sovetskaia istoricheskaia nauka za 25 let $\mathrm{i}$ zadachi istorikov v usloviiakh velikoi otechestvennoi voiny," in Dvadtsat' piat' let, pp. 30 and 28. 
That he retreated from the more ambitious comparative investigation essayed in his candidate's dissertation suggests a growing realization that a lone scholar could scarcely accomplish such a monumental undertaking. His decision may also have been influenced by pressures from two opposite directions. At one extreme, the Leningrad historian I. I. Smirnov peremptorily dismissed the theoretical value of his candidate's work. ${ }^{59}$ At the other extreme, Veselovskii questioned the soundness of the results. ${ }^{60}$ The former rejected the approach on grounds that it was irrelevant to the current debate on feudalism. The latter argued that the requisite primary and secondary materials could not be mastered. Whatever Cherepnin's private reasons, however, comparative investigation soon ceased in any case. It fell victim to the intellectual ethnocentrism cultivated during the postwar period, especially during the anticosmopolitan campaign. Cherepnin would pursue instead the close critical analysis of the princely testaments and treaties alongside other Russian sources, the approved method of his early training.

By the end of the 1930 s, the renovated higher research institutes had responded to the urgent call for a new, acceptable Marxist-Leninist formulation of the Soviet past which would reconcile formula with fact, the theoretical with the concrete, socioeconomic formations with traditional periodization. The process had involved great professional and personal readjustment, for Cherepnin no less than for those with weightier responsibilities. Not simply to follow but to lead the redirection of historical scholarship in the menacing atmosphere of Stalin's personal rule was what the regime asked of an older generation of historians and their students, many of whom lacked the requisite theoretical preparation, many of whom faltered in their appropriation of the new language. Much later, one Soviet historian pointed to the consequences of the situation for the study of feudalism. L. V. Danilova has argued that to entrust to historians who had only recently come to Marxism the task of continuing from what she regards the high

59. Smirnov writes: "Placing before himself the task of studying the system of relations of domination and subordination in the estates of the Moscow metropolitanate, . . . Cherepnin, instead of analyzing the essence of these relations in their historical development, went along the path of purely external comparison of discrete historical institutions of Russian feudal law of the fourteenth to sixteenth centuries with analogous institutions of the Western European Middle Ages. But what was original and valuable in the time of Pavlov-Silvanskii at the end of the nineteenth century could scarcely satisfy anybody in 1940" (I. I. Smirnov, "Problemy krepostnichestva i feodalizma v sovetskoi istoricheskoi literature," in Dvadtsat" piat' let, p. 98). The very title of the article stresses the shift in the debate's direction since the early 1930s (cf. Grekov, "Osnovnye itogi," pp. 85-87, and S. V. Bakhrushin in Protiv istoricheskoi kontseptsii Pokrouskogo, vol. 1, pp. 118-19, on the state of the debate).

60. The well-known position of Veselovskii was repeated in his introduction to Feodal'noe zemlevladenie. He cautioned about the hazards of using unevenly distributed sources, which, for the earliest period, are juridical memorials that only indirectly, and not always satisfactorily, elucidate essential questions of economics and then largely for the holdings of the monasteries which preserved them (Veselovskii, Feodal'noe zemlevladenie, pp. 8-9). He also stated that the comparative method had been abused by those who wrenched phenomena from the context of historical conditions of time and place, by those who were unable to distinguish the essential and constant from the external and accidental, and by those who were scarcely able to master the vast source materials on the Russian side, not to speak of the voluminous and rapidly changing Western literature on Western phenomena that exhibit extraordinary diversities and peculiarities (ibid., pp. 14-16). Cherepnin was associated with the publication of this very controversial work in 1947; his bibliography mentions membership in the group that prepared the anonymous critical introduction to the work. 
point of the assimilation of Marxist teaching on feudalism in 1929-30 could not fail to foster avoidance of theoretical and methodological discussion, to reinforce dogmatism and substitute citation for sociology, to reinvigorate the traditions of the bourgeois state-juridical school, and to encourage the display of Great Power chauvinism and subjectivism in the evaluation of persons, facts, and events. These characteristics, prolonged in her view by the persistence of Stalin's cult, allowed significant advance only in such areas as the accumulation of concrete knowledge, the elaboration of discrete themes, the study of sources, archeography, and other ancillary disciplines. ${ }^{61}$ For the moment, however, these consequences were overwhelmed by the cataclysm of war, only to revive with greater virulence in the aftermath of victory.

$\mathbf{V}$

Cherepnin resumed formal residence in Moscow during World War II. In 1942, he accepted A. I. Andreev's invitation to teach at the Historical-Archival Institute, he defended his candidate's dissertation at the Moscow City Pedagogical Institute named after Lenin, and he entered the doctoral program of the Institute of History. The six years between his acceptance as a doctoral candidate and the publication of the first volume of his doctoral dissertation exhibit his remarkable capacity for work and the high quality of his scholarship. He taught at three institutions besides the Historical-Archival Institute-Moscow University from 1944 and the Institute of International Relations and the party's Academy of Social Sciences from 1946. He completed three textbooks on metrology, chronology, and paleography (the last with N. S. Chaev) in 1944 and 1946. He defended his doctoral dissertation, written under the direction of S. V. Bakhrushin, in 1946. He prepared for publication the Law Codes of 1497 (1947) and 1550 (1948). ${ }^{62}$ In addition to several book reviews, he published seven important articles in the area of source study. In 1947, he helped introduce, anonymously, the valuable monograph of his colleague and former teacher, S. B. Veselovskii, Feudal Landholding in Northeast Rus'. This circumspect preface, while criticizing the book's alleged failings, stressed the outstanding significance of the work, its contribution of new facts, deep and subtle observations, valuable constructs, and well-grounded conclusions on a number of specific questions. ${ }^{63}$ No less can be said about Cherepnin's own scholarly work during this period.

61. Danilova, "Stanovlenie," pp. 63-64, 113-19. She criticizes severely those in the 1930 s who valued Petrushevskii, I. M. Grevs, and Veselovskii as the principal legacy of Soviet historiography of the 1920s. In conclusion she insists that scholars from bourgeois schools came to play an active role in the study of the feudal period only in the second stage of Soviet historiography. The first stage is reserved for those like Pokrovskii who came to the discipline from the Revolutionary struggle and who spoke from Marxist positions prior to 1917 as well as to the younger generation of specialists who were educated in the 1920 s in the Soviet higher schools (ibid., p. 119). Danilova's article allows one to speculate that those Soviet historians whose primary scholarly concern lay in theoretical questions were among those who most strenuously opposed the abuses of Stalin's cult.

62. V. Shunkov, "Institut istorii AN SSSR v 1947 godu," VI, 1948, no. 5, p. 137. They were not published for several years.

63. Veselovskii, Feodal'noe zemlevladenie, pp. 1-4. The introduction criticizes Veselovskii for concentrating on questions of law to the exclusion of basic themes of feudalism as a social form and cautions the reader against being misled by Veselovskii's analysis to see the boyars as the politically and economically advanced element in society and the enemies of feudal fragmentation. 
All seven source studies anticipate the doctoral dissertation in subject or method. They concern the "New Chronicler" (1945), ${ }^{64}$ the "Charter of Pskov" $(1945){ }^{65}$ the archives of the Moscow grand princes (1946), ${ }^{66}$ the Novgorod treaties (1946), ${ }^{67}$ the "Charter of Novgorod" (1947), ${ }^{68}$ the treaties and testaments of Dmitrii Donskoi (1947), ${ }^{69}$ and the "Tale of Bygone Years" (1948). ${ }^{70}$ Only the first and the last do not form part of the dissertation. In the first, Cherepnin demonstrated most effectively the analytical approach to sources that molded each of his publications from the "Capitulare de villis" to the doctoral dissertation. In the second, he prefaced the source analysis with an eloquent acknowledgment of the immense debt owed by the discipline and by the author personally to A. A. Shakhmatov. (It is the only one of its kind in his published work.) Common to all seven articles are not only the highest scholarly standards and the dependence of conclusions on textual analysis alone but the emergence of the central and recurring theme that so plainly fascinated the author and found so brilliant a development in his doctoral dissertation-"the reworking of historical materials for political purposes." 71

The article, "The Time of Troubles' and Historiography of the Seventeenth Century," analyzes several manuscripts of the "New Chronicler" (1630) as a stage in the general evolution of Russian historiography from the sixteenth-century Book of Degrees to the first eighteenth-century gentry historians. Cherepnin furnishes a detailed and painstaking study of the document's sources, process of composition, relation to contemporaneous memorials, political tendencies, and influence on seventeenth-century historiography. The document, he concludes, was confected in the ambassadorial department and Patriarch Filaret's court. In the former, archival sources were collected and excerpted; in the latter, they were reworked in a literary narrative presented for Filaret's approbation. The principal goal of the compilers, he writes, was to prepare an apology for absolutism which reinforced the legitimacy of the Romanovs' dynastic claim, while denigrating Boris Godunov and Vasilii Shuiskii. Cherepnin skillfully dissects the intricate political, social, and diplomatic circumstances that affected the evolution of the underlying conception. Alongside the source analysis proper, he attempts to connect the chronicle's vitriolic indictment of Pretenders to evidence gleaned entirely from the Novombergskii documents (1911) about social unrest and political

64. L. V. Cherepnin, "'Smuta' $\mathrm{i}$ istoriografiia XVII veka," $I Z, 14$ (1945): 81-128.

65. L. V. Cherepnin, "K voprosu o proiskhozhdenii i sostave Pskovskoi Sudnoi Gramoty," $I Z, 16$ (1945): 203-31.

66. L. V. Cherepnin, "Dokumenty Moskovskogo velikokniazheskogo arkhiva i ikh znachenie v politicheskoi bor'be pri Ivane III," Trudy istoriko-arkhivnogo instituta, vol. 2, pp. 3-67.

67. L. V. Cherepnin, "Proiskhozhdenie sobraniia dogovornykh gramot Novgoroda s kniaz'iami XIII-XV vv.," IZ, 19 (1946) : 215-33.

68. L. V. Cherepnin, "Sostav i proiskhozhdenie Novgorodskoi Sudnoi Gramoty," $I Z$, 21 (1947) : 222-53.

69. L. V. Cherepnin, "Dogovornye i dukhovnye gramoty Dmitriia Donskogo kak istochnik dlia izucheniia politicheskoi istorii velikogo kniazhestva Moskovskogo," IZ, 24 (1947) : 225-67.

70. L. V. Cherepnin, “'Povest' vremennykh let,' ee redaktsii i predshestvuiushchie ei letopisnye svody," IZ, 25 (1948): 293-333.

71. L. V. Cherepnin, "'Smuta' i istoriografiia," p. 83. 
activity among peasants, Cossacks, and petty servitors in border areas in the 1620 s and 1630s. Cherepnin persuasively argues that "the line on the Time of Troubles was not worked out at one time," but, once defined, it profoundly influenced later histories, from those of the seventeenth century to Platonov.

The article "The 'Tale of Bygone Years,' its Redactions and Preceding Chronicle Codices" appeared inconspicuously in the journal Istoricheskie zapiski (1948) under the rubric "Criticism and Bibliography." It joined the current agitated debate over the significance and relevance of A. A. Shakhmatov's scholarly legacy. Cherepnin's spirited defense of his predecessor's methods, if not his conclusions, was built on ground prepared by Grekov's Peasants in Rus' from Ancient Times to the Seventeenth Century (1946) and the Shakhmatov materials published by the Commission on the History of the Academy of Sciences (1947).$^{72}$ This tribute properly introduces the aspirations and approach that shape the first published volume of Cherepnin's doctoral dissertation, dated 1948, the same year as his article.

Hailing Shakhmatov's work as "an epoch in the study of the 'Tale' and of Russian chronicles generally," he continued:

A. A. Shakhmatov destroyed the boundary which separated historical source study from historical investigation. He demonstrated that if one does not approach the source formally, it is itself a historical phenomenon closely tied with all other phenomena of socioeconomic and political life.

A. A. Shakhmatov examines each individual source in close interaction with all those surrounding it. Characteristic for him are an unusual sweep of historical thought and a grandiose scale of work, the bringing to bear of the greatest number of chronicle copies as well as other literary memorials. ...

A. A. Shakhmatov examines each source as something complete in itself, distinguished by a certain idea content and a particular literary genre. At the same time, the source interests Shakhmatov in its movement. He reveals its creative history, its path of development. He defines the sources of the document, and so forth. ...

With exceptional daring and with intuition that never lapses into fantasy, A. A. Shakhmatov reconstructs chronicle texts which have not come down to us. This is done by comparing numerous chronicle copies among themselves and with other literary memorials. . . .

Shakhmatov's method far exceeds the limits of the study of chronicle texts. Its application to the analysis of legislative memorials and documentary materials gives brilliant results. ${ }^{73}$

Such brilliant results crowd the pages of Cherepnin's dissertation. And no observer can better convey the values Cherepnin deeply prized and stubbornly sought to realize in the life of the mind-the inviolability of evidence, thoroughly and conscientiously collected, the rigorous use of logic to advance from the specific to the general, and, not the least, the exceptional daring, the leap of intuition that never lapses into fantasy.

72. Akademiia nauk, Kommissiia po istorii. Trudy, vol. 3: A.A. Shakhmatov: 1864-1929; sbornik statei i materialov (Moscow, 1947).

73. Cherepnin, "'Povest' vremennykh let," " pp. 293-94. 
Cherepnin's central concern in part one of Russian Feudal Archives is to analyze in both static and dynamic dimensions the documentary legacy of the Moscow grand princes' archives, more specifically their principal components: the testaments and treaties of the fourteenth and fifteenth centuries as well as three legislative memorials found there, the Novgorod, Dvina, and Pskov Charters. $\mathrm{He}$ accepts that "the theoretical prerequisites for further profound investigation of the socioeconomic and political history of northeast Rus' in this period have been laid in Soviet historical scholarship." But his own work proceeds from the proposition that "this study can be fruitful only if there is first done the critical working through of the sources of the period." 74 Such preparation of the source base would on the one hand lay the foundation for the "building of MarxistLeninist source study."75 It would serve on the other hand "as the means to pose a whole series of problems concerning the formation of the Russian state."76

In this vast undertaking, the author deemed it essential to apply to public documents "those approaches of the critical working through of memorials which Soviet investigators use in studying chronicle texts."77 For each source, he collected and compared the extant manuscripts, in many cases introducing new materials and illuminating the process of compilation. His laborious examination of individual documents addressed not only contents, but also external characteristics, a method which displayed his mastery of auxiliary disciplines like paleography and sphragistics and yielded often provocative observations on the political meaning of his sources. Not content to formulate his interpretations on the basis of manuscript evidence alone, Cherepnin enriched his search for "the historical conditions that gave rise to the document" by reference to contemporary sources, primarily the chronicles.

The author strove, moreover, to discover the relation of the individual document to the archives in which it was found. The very contents and form of the archives suggested to him an integrity, a unifying purpose. Indeed, "the process itself of concentration could be shown to reflect the political history of the Moscow princedom." "No one," he avers, "has yet paid attention to the fact that documents preserved their political significance long after their composition."78 Thus he seeks to reveal the meaning of the source for its own and for later times. On these two levels one must understand his statement of purpose: "The subsequent investigation elucidates, first and foremost, the role of documents of the grand princes' Moscow archives of the fourteenth and fifteenth centuries in the political life of the times, in the struggle which the Moscow princes waged with the grand princes of Riazan' and Tver', with the free cities of Novgorod and Pskov, with the Golden Horde, with the Polish-Lithuanian state."79

Cherepnin is particularly attentive to the matter of dating, both with regard to the document's origin and its later political use: "The true understanding of political meaning depends on dating." 80 Revising the dating of various sources,

74. Cherepnin, $R F A$, part 1, p. 4.

75. Ibid., pp. $4,448,456$.

76. Ibid., p. 9.

77. Ibid., pp. 5, 6 .

78. Ibid., p. 11.

79. Ibid., p. 12.

80. Ibid., p. 14. 
including the Pskov Charter, he establishes a carefully corrected chronology of the advance of Moscow's cause. As he proceeds, he conducts a continuous scholarly debate with his predecessors-such as Solov'ev, Ekzempliarskii, and especially Presniakov--methodically accepting, modifying, or rejecting their carefully summarized views on given points of interpretation. He interprets later annotations, additions, and corrections on original manuscripts and analyzes the structure and contents of later collections of copies from earlier materials. In addition, he combines his study and comparison of individual documents with interpretation of sixteenth- and seventeenth-century archival inventories, especially the 1626 inventory of the Posol'skii prikaz, to reconstruct defective texts and to advance cautious hypotheses regarding the existence and contents of lost documentary links. Document by document, reign by reign, he moves patiently and relentlessly through the intricacies of his evidence, from Ivan Kalita to Ivan III.

Political ambition found new uses in the last decades of the fifteenth century for memorials accumulating in scattered repositories. In Cherepnin's own words:

Feudal wars took place not only with weapons in hand on the battlefield. These wars took the form of "wars of words," when the weapon of the protagonists was documents. Princes blinded and poisoned one another; they incarcerated one another in exile. But princes at the time of their conflicts also carried away with them the archives of others. They suppressed and destroyed these documents, understanding their political force. . . . For Ivan III these archives were not dead treasure. The creative work of state-building proceeded over their contents. ${ }^{81}$

Cherepnin's chapter on Ivan III stands as the centerpiece of the volume. Toward it lead the systematic studies of testaments and treaties recording policies and achievements of Ivan's forebears; from it proceeds the complex analysis of the treaties and legislative charters of Novgorod and Pskov; in it is explored the meticulous reworking of the documentary legacy to further Moscow's unifying policies. Cherepnin explores how the testaments and treaties of Ivan's predecessors were cited in negotiations, how new formulae were elaborated for both treaties and testaments on the basis of old texts, how historical tradition was arbitrarily distorted and violated, how documents were selected, systematized, and even destroyed by chancery clerks-all in the service of immediate political tasks. ${ }^{82}$

Cherepnin concludes that "the grand princes' archives were formed from collections of the appanage princes of Galich, Mozhaisk, Serpukhov-Borovsk, Vereisk, and others which Moscow gathered after these appanages fell to Vasilii the Dark and Ivan III. They contain, moreover, remains from archives of the grand princes of Riazan' and Tver', brought to Moscow in the second half of the fifteenth century." 83 He concludes that the entire Novgorod complex of documents passed to Moscow indirectly through Tver', while copies from Novgorod materials assembled in the 1470 s were chosen and rearranged according to a definite principle that promoted Moscow's political and jurisdictional claims against the

81. Ibid., p. 161.

82. Ibid., p. 162.

83. Ibid., p. 6. 
city. ${ }^{84} \mathrm{He}$ dissects the structure and contents of the Novgorod, Dvina, and Pskov Charter manuscripts and reveals in them efforts by Moscow to centralize legislation. ${ }^{85}$ (Analysis of the Law Code of 1497 closes the second published volume of Cherepnin's dissertation.)

The contents and value of Cherepnin's study cannot be conveyed adequately in this space. His own conclusion fails to do justice to the complexity and subtlety of the work. Densely composed and closely argued, this book is not for those seeking broad general answers to large questions. For all its attention to minutest details, however, the documentary analysis is permeated with a dramatic tension that derives from brilliance of argument rather than excellence of style. (The very same technique riveted Cherepnin's audience in the lecture hall.)

The author returned frequently in his introduction and conclusion to the obligation of Soviet source study to illuminate socioeconomic and political questions, "class direction and political purposefulness," "the class and political meaning of documents." ${ }^{86}$ As his earlier candidate's work had already demonstrated, however, the principal extant archival sources-the testaments and treaties-pose a serious dilemma for the Soviet scholar. They offer little for socioeconomic analysis. "These documents," Cherepnin acknowledged, "characterize mainly the political side of the process of the formation of the Russian state." A second group of sources for the period, the metropolitan and monastic archives, he asserted, would "afford material for characterizing the Moscow feudal system of economy and the position of the class of direct producers." $\mathrm{He}$ devoted the second part of his dissertation to those sources. ${ }^{87}$

Among other major and minor objections, the principal reviewers in Voprosy istorii criticized the monograph's structure, attributing it to "the influence of traditions of bourgeois historians who undervalue socioeconomic documentation and problems." Nevertheless, they judged the book "a serious contribution in the matter of developing Soviet source study."88 Within the limits of his chosen source base, Cherepnin's achievement was surely extraordinary. The creative extension of his predecessors' methods to a new body of source material, which left on the analysis the bold stamp of his own formidable talent and personality, provided a model of the highest professional standards and a catalyst for the scholarly achievements of a host of able followers. The monograph constituted a bridge between the old and new worlds, insofar as it transmitted the fruitful techniques pioneered by predecessors into what was eventually recognized as a foundation of Soviet archeography. At the time of its appearance, however, the work won no prize.

This first essay on Cherepnin's route to the summit of his profession draws to a close with the appearance of the first of his monumental two-part monograph, authorized for the press on November $11,1948 .^{89}$ To review part one alone will

84. Ibid., p. 8, and chapters 5 and 6 .

85. Ibid., p. 9, and chapters 6 and 7.

86. See, for example, ibid., pp. 4-9 passim.

87. Ibid., pp. $457,461,9$.

88. A. Zimin and V. Pashuto, VI, 1949, no. 9, pp. 119-22. The discussion of the monograph at the Institute of History was reported in Vestnik, 1949, no. 8, pp. 83-85. (The actual defense of the doctoral dissertation in 1946 was not reported in $V I$.)

89. Cherepnin, $R F A$, part 1, p. 472. 
appear artificial. Beyond mere limits of space, however, there is reason to do so. Three years separated the publication of the two parts, although the companion volume was initially ready for the printer in $1948 .^{90}$ During the interval, the historical discipline underwent profound changes, not as drastic in their personal consequences as those of the late 1920 s or mid-1930s, but no less significant in their professional impact. Historians and other intellectuals experienced yet another major crisis, a turning point which for many of them exacted an agonizing reorientation of their approach to scholarship and for a time set back and, in the last analysis, seriously affected the appearance of their work. Cherepnin was no exception.

The growing turmoil left traces on Cherepnin's published monograph, seen in the introduction and especially in the conclusion. The former opened with a brief, hurried survey of the author's precursors-Pavlov-Silvanskii, Beliaev, Veselovskii, Presniakov, Liubavskii, Shakhmatov, Lappo-Danilevskii, Grekov, and others. The author sought to distinguish "Soviet" from "bourgeois" source study, "Soviet" from "bourgeois" views on the formation of the Russian state. (The latter was set in a three-line context of Stalin's remarks on "the requirements of self-defense' as the accelerating moment of the creation of 'centralizing states' in the east of Europe and the role of Great Russians as the 'unifiers of nationalities." ") He reproached his predecessors for "divorcing the political side of the process of state formation from economic development and the phenomena of class struggle."91 This historiographical exercise, as if found wanting, was repeated in the opening pages of the conclusion, this time at greater length and with heightened invective. There it was argued that "Marxist-Leninist dialectic allows the creation of genuinely scientific source study, demonstrating the complete methodological impotence of formal neo-Kantian logic in this regard."92 This incongruous accretion, so alien in tone and substance to the monograph itself, suggests that part one had already been set in type when new urgent demands pressed upon the author. (Part two had not. Before its publication in 1951 it would be thoroughly reworked to satisfy even more stringent standards and demands.) To appreciate the scope and menace of those demands, one must turn from the layered text of the monograph to the basic chronicle of this period available to students of Soviet historiography: the scholarly and popular press.

vi

The official campaign to reeducate Soviet society in a spirit of ideological conformity and militant party-mindedness commenced almost immediately after World War II. Its effects racked the professional organizations of Soviet intellectuals for years. The objectives, vocabulary, and tone of the campaign could be studied in several directives on ideological work issued by the Central Committee and in public speeches and discussions connected with the name of A. A. Zhdanov, its most vociferous spokesman. The campaign did not aim to renovate the ranks of intellectuals, as in the previous decade, but rather to render them more submissive to party control and more active in support of a fierce assertion of ideologi-

90. Ibid., pp. 9 and 448.

91. Ibid., p. 4.

92. Ibid., p. 453 . 
cal and national superiority. Intellectuals were called upon to end their ideological and political apathy, to cease their kowtowing before things foreign (nizkopoklonstvo pered inostranshchinoi), to exterminate all remnants of "bourgeois objectivism," and to emphasize the independence of Soviet cultural and scientific achievements.

The campaign spared neither the historical profession nor its "mightiest and most authoritative scientific collective," the Institute of History. Relative tolerance for diverging views, evident in the major postwar debate on state centralization, gave way by 1948 to full-scale attack on vestiges of professional autonomy. By 1949, political aloofness was virtually equated with treason; "bourgeois objectivism" had become "bourgeois cosmopolitanism," "the ideological weapon of Anglo-American imperialism which aspires to world domination and aims to unleash war against the Soviet Union and the countries of the peoples' democracies."93

The full force of the new direction struck the institute in the last months of 1948 and the first months of 1949 . It would appear from the printed evidence that the institute at first withstood the pressures from within. It could not withstand the assault from without. In September 1948, Kul'tura $i$ zhizn' and Literaturnaia gazeta attacked the institute and certain of its "low quality, often anti-Marxist, politically harmful, and ideologically defective historical works." ${ }^{94}$ On October 15, 1948, the institute's director, Academician B. D. Grekov, opened the doors; "public" meetings laid bare the alleged mistakes, distortions, defects, and shortcomings in the work of the institute and its members. In this and subsequent months, specific charges and ominous innuendos hailed down on the institute's leadership, party organization, sector heads, publications, associates, and journals.

"Historians forgot that all directives of the CC VKP(b) in their entirety apply to them. Historical science . . . like any other science must be first and foremost a party science." So railed the rapporteur of the October meetings on the pages of Voprosy istorii. ${ }^{95}$ The lead editorial in the December journal brought the issue into focus: "The watershed separating the Marxist from the objectivist is a consistently pursued principle of the class analysis of historical phenomena and consistently pursued party-mindedness in the evaluation of these phenomena."96 Objectivist positions had been disseminated most extensively in works on historiography, the anonymous author wrote; they "lead inevitably to a blunting of the critical sense with regard to bourgeois science and contribute to the surreptitious introduction of bourgeois views into our historical literature." ${ }^{\prime 27}$ The "classic" example of bourgeois objectivism was N. L. Rubenshtein's Russian Historiography (1941). In March 1948, the Ministry of Higher Education had organized an all-union meeting of heads of history departments in order to expose the perniciousness of the work and its underlying proposition, "the bourgeois-

93. A. V., "Zasedanie uchenogo soveta Instituta istorii AN SSSR. 24-28 marta 1949 goda," VI, 1949, no. 3, p. 152.

94. A. Krotov, "Primirenchestvo i samouspokoennost'," Literaturnaia gazeta, September 8, 1948, p. 2. See also S. Pavlov, "Ob"ektivistskie ekskursy v istoriiu," Kul'tura $i z h i z h^{\prime}, 27$ (82), September 21, 1948.

95. Z. Mosina, "O rabote Instituta istorii AN SSSR," VI, 1948, no. 11, p. 146.

96. "Protiv ob"ektivizma $v$ istoricheskom nauke," VI, 1948, no. 12 , p. 8.

97. Ibid., p. 10. 
objectivist point of view toward historical science as a process of the progressive accumulation of knowledge about society, as a smooth evolution of the history of ideas." 98

The litany of charges rehearsed at institute and sector meetings in this period recalls the accusations and frustrations of an earlier period. The resolution of the Scholarly Council ending the October 1948 meetings reduced the charges to the following:

(a) insufficient mastery of Marxist-Leninist theory and particularly the inability of a number of institute associates to apply this theory to the study of concrete historical reality and insufficient concern of the institute leadership for raising the level of Marxist-Leninist preparation of associates; (b) insufficient attention of the leadership of both the institute and the sector, as well as of the associates in general, to problems of a principled theoretical character and excessive enthusiasm for factology; (c) absence in sectors and in the institute of daring criticism and self-criticism. ${ }^{99}$

Critics of the institute's work overlooked no sector. They excoriated specialists on the Soviet period for failing to deliver monographs, articles, textbooks, research associates, and even a director for the sector on Soviet society. ${ }^{100}$ They indicted the medievalists for publishing a symposium in 1947 dedicated to D. M. Petrushevskii in which the contributors called themselves preservers and direct continuers of the traditions of his school. ${ }^{101}$ They fell with particular force, however, upon historians of Russia to the nineteenth century, the sector led by S. V. Bakhrushin. From here had come three works which drew the heaviest fire in the press: S. B. Veselovskii's Feudal Landholding (1947), the symposium Peter the Great (1947), and I. U. Budovnits's Russian Publicist Writings of the Sixteenth Century (1947). If the critics denounced the "reactionary," "idealist," and "anti-Marxist" positions of the first, they deplored no less the sector's anonymous introduction to it. (I. I. Smirnov, for example, charged that the introduction's polemic with this anti-Marxist work concentrated on "discrete questions of secondary importance" and even "played down the methodological defects.") ${ }^{102}$ With regard to the second volume, critics thundered that A. I. Iakovlev's article for the Newton jubilee (1942) exaggerated England's influence on the Petrine reforms, while S. A. Feigina's bibliographical essay paraded the "mendacious, slanderous fabrications" of "bourgeois, even fascist authors."103 The public meet-

98. Ibid., pp. 8 and 10. See also Mosina's demonstrative quotation of A. A. Zhdanov's attack on G. F. Aleksandrov's History of Western European Philosophy in 1947: "He [Aleksandrov], without realizing it perhaps, was a prisoner of bourgeois historians of philosophy who proceed from the fact that they see in every philosopher first and foremost a colleague in the profession and then only a protagonist. Such conceptions, if they develop here, inevitably lead to objectivism, to kowtowing before bourgeois philosophers and exaggerating their merits, to depriving our philosophy of a militant, aggressive spirit" (Mosina, "O rabote Instituta," p. 147).

99. Ibid., p. 148.

100. See, for example, ibid.

101. "Protiv ob"ektivizma," p. 6. See Srednie veka, E. A. Kosminskii, ed., no. 2 (MoscowLeningrad, 1946).

102. I. Kudriavtsev, "Ob 'Istoricheskikh zapiskakh' Instituta istorii AN SSSR," VI, 1948 , no. 10 , p. 124.

103. Mosina, "O rabote Instituta," pp. 144-45. 
ings at the institute in October 1948 propelled the attack beyond the targets named in the press: to A. I. Iakovlev for his assessment of Kliuchevskii, to A. I. Andreev for his assessment of Solov'ev, and to L. V. Cherepnin for his assessment of Shakhmatov. ${ }^{104}$

The burden of answering for the sector fell on S. V. Bakhrushin. In meeting after meeting during this period he heard explicit and implicit criticism directed at himself personally, at his colleagues, and at the work of the sector. He was explicitly accused of publishing the Petrine symposium against the advice of a majority of his associates, ${ }^{105}$ of tolerating in his sector "the burning of incense before outstanding representatives of gentry-bourgeois science," 106 of refusing to insist on historiographical introductions to doctoral dissertations, ${ }^{107}$ of failing to make clear how he proposed to mobilize his associates for the "irreconcilable struggle against bourgeois historiography," 108 and of passing over in silence the most important shortcomings of his sector's work, particularly the survivals of bourgeois historiographical views. ${ }^{109}$ Nor could he escape the more general indictments. There were sectors where young scholars retreated from theoretical questions to "collectionize" facts; where young scholars chose themes that "allowed them first and foremost to shine with knowledge of the sources, to introduce new factual material ladled from the archives," where dissertation directors valued the work of young scholars to the degree they used "new materials and provided a sufficient number of quotations and references to sources" and cared not at all whether "the young scholars make even the slightest effort to generalize these facts, in what direction these generalizations are made, and to what theoretical conclusions they come."110 (V. V. Kafengauz and L. V. Cherepnin were censured at a sector meeting in October 1948 for failure to "draw from their large investigations all the necessary conclusions" and "to provide substantial historiographical surveys criticizing bourgeois historiography and the mistakes in contemporary historiography.") ${ }^{111}$

The Scholarly Council's resolution at the close of the public meetings in October 1948 admitted that the institute had not implemented the Central Committee's directives on ideological work "in a timely manner or to the required degree."112 Indeed, the various and vituperative sorties against the institute's activities during this period reveal efforts to ignore, deflect, and resist the assault.

104. Ibid., p. 145. It should be noted that while Iakovlev and Andreev were attacked, Cherepnin criticized himself. At the sector meeting of October 21, 1948, Cherepnin was no longer listed with the two others, and he spoke of the need to provide a substantial criticism of Shakhmatov's bourgeois method. At the same meeting, however, his dissertation was charged with "crucial deficiencies" ("V Institute istorii AN SSSR," p. 172).

105. Mosina, "O rabote Instituta," p. 145.

106. Ibid., p. 147.

107. "V Institute istorii AN SSSR," p. 172.

108. Mosina, "O rabote Instituta," p. 145; "Protiv ob"ektivizma," p. 172.

109. A. V., "Zasedanie uchenogo soveta Instituta," p. 153.

110. Mosina, "O rabote Instituta," p. 147.

111. "V Institute istorii AN SSSR," p. 172. Just this second "shortcoming" appears to have been addressed in a reworked conclusion. The summons to criticize not only the "bourgeois" tradition but Soviet scholarship as well suggests why Cherepnin included Grekov and other contemporaries in his survey. About three weeks separated the sector meeting from the authorization to print the manuscript.

112. Mosina, "O rabote Instituta," p. 148. 
The lead editorial in Voprosy istorii in December 1948 complained that the institute had done almost nothing to execute the party's instructions to struggle against bourgeois ideology, especially bourgeois historiography; that it had responded "weakly" to the party organization's call to struggle against kowtowing before the West and had done nothing to expose the false versions of Russia's cultural and scientific dependence; that authors of defective works had yet to assimilate the basic principles of Marxist-Leninist methodology and had either retained their positions of bourgeois objectivism or slipped back from Marxism-Leninism into bourgeois objectivism. ${ }^{113}$ The institute, it was reported, had ignored the key discussion (1947) of G. F. Aleksandrov's History of Western European Philosophy. ${ }^{114}$ It sent no representatives to the all-union discussion of Rubenshtein's Russian Historiography and, even more, "failed to draw from it the necessary conclusions." 115 Only after considerable delay had it responded to "nationalist distortions in the work of fraternal Soviet republics," and it had yet to proffer adequate help to republican historians writing the history of the peoples of the USSR. ${ }^{116}$ Research associates were accused of trying to limit themselves to purely "formal" self-criticism and trying to narrow the scope of debate at the public meetings. ${ }^{117}$ There were even cases when the institute met criticism with "bayonets fixed," for example, in Bakhrushin's sector with regard to the Petrine symposium. ${ }^{118}$ And at the October meeting of this same sector, just those associates under attack by the Soviet public absented themselves. ${ }^{119}$

Resolutions of the Scholarly Council and editorials in Voprosy istorii proposed remedies. An irreconcilable struggle was promised against hostile influences and survivals of bourgeois ideology, especially in the works of the institute itself. ${ }^{120}$ The Short Course of the History of the $V K P(b)$ was recommended to historians as "the model of a scientific work which harmoniously fused rich factual materials with deep Marxist analysis, a high theoretical level with simplicity and accessibility of exposition." 121 A "fundamental rebuilding of the entire work of the institute" was deemed necessary, one in which criticism and selfcriticism would be the basic method of training cadres and raising the level of work. ${ }^{122}$ Institute members were urged to cast off the entrenched and "rotten tradition of refraining from criticism of those senior in academic rank." 123 They were told to scrutinize their own work and that of others. The purpose by spring 1949 was to detect "antipatriotic, cosmopolitan distortions." 124 As for the sector on the history of the USSR to the nineteenth century, Bakhrushin indicated in October 1948 that the "creative work of the sector had to move not only along the line of critical analysis but-and this was the main thing-also along the line

113. "Protiv ob"ektivizma," pp. 4 and 8.

114. Mosina, "O rabote Instituta," p. 147.

115. Ibid.; "Protiv ob"ektivizma," p. 5.

116. Mosina, "O rabote Instituta," p. 147.

117. Ibid., pp. 144-45.

118. "Protiv ob"ektivizma," p. 12.

119. "V Institute istorii AN SSSR," p. 172.

120. Mosina, “O rabote Instituta," p. 148.

121. "Protiv ob"ektivizma," p. 3.

122. Ibid., p. 12.

123. Ibid.

124. A. V., "Zasedanie uchenogo soveta Instituta," p. 154. 
of creating a new Marxist historiography that would be the strongest weapon in the struggle against bourgeois historiography." ${ }^{125}$

When B. D. Grekov addressed the public meetings of October 1948, he chose his words carefully. He expressed full assurance "that the collective of the institute would find in itself the strength and the courage to the very end to take cognizance of its mistakes and overcome them in future work." 126 The alternative was clear to all. If not, a transparent threat ended the official report:

One can conclude that the leadership of the institute and its associates learned with basic correctness the serious lesson emerging from criticism of the institute's work. But one must say that earlier too the Scholarly Council managed to work out splendid resolutions. And all the same these resolutions did not save the institute from that grave downfall which was alluded to at the meetings of the Scholarly Council. ${ }^{127}$

The "grave downfall" of 1930 was not repeated two decades later. The institute survived the crisis, but not without radically altering its patterns of work and severely straining the bonds of collegiality welded by the common experience of toil and war. How does one begin to comprehend this period as it bore down on the lives of institute associates? To gauge the vulnerability and anguish of Cherepnin's position, need one do more than recall in the context of the anticosmopolitan campaign Cherepnin's scholarly, professional, and personal ties to certain of its principal targets-Pavlov-Silvanskii and Shakhmatov, Petrushevskii, Iakovlev, and Andreev, Veselovskii and Bakhrushin? For many historians the process of "reforging" during the early 1930s took place in prison or exile. It now took place on the job. Cherepnin passed through it during the interval that separated publication of the two parts of his monograph. During those years his energies were redirected to areas where he was as yet untested-to historiography, the history of Moldavia, theory, and administration. ${ }^{128}$ (In 1951 he assumed the burden of leading a reorganized sector, now called History of the USSR of the Feudal Period. It was relinquished by his teacher, adviser, colleague, and friend, S. V. Bakhrushin, who died in March 1950 and whom Cherepnin honored in an anonymous obituary in Voprosy istorii. ${ }^{129}$ ) As in an earlier difficult period, Cherepnin's ability to pursue new directions successfully would depend on the support of loyal colleagues, those who, like his collaborator V. T. Pashuto, possessed the new skills required of Soviet historians, thereby complementing the strengths of his early training.

125. "V Institute istorii AN SSSR," p. 172.

126. Mosina, "O rabote Instituta," p. 144.

127. Ibid., p. 149.

128. See, for example, his articles on Lappo-Danilevskii (VI, 1949, no. 8, pp. 30-51) and Presniakov (IZ, 33 [1950]: 203-31); his contribution to the lead editorial on the basic tasks of studying the history of the USSR in the feudal period (VI, 1949, no. 11, pp. 3-12); his articles on the periodization of Russian history of the feudal period (VI, 1951, no. 2, pp. 52-80 [with V. T. Pashuto]); Izvestiia $A N$ SSSR. Seriia istorii $i$ filosofii (9, no. 2 [1952]: 115-32); and on Stalin (see above note 13). Cherepnin's role in establishing the historical profession in Soviet Moldavia is described by Ia. S. Grosul and N. A. Mokhov in Obshchestvo, pp. 9-12.

129. [L. V. Cherepnin], "S. V. Bakhrushin," VI, 1950, no. 3, pp. 157-59. 
New responsibilities could delay but not deter Cherepnin from pursuing his principal theme-state centralization in the fourteenth and fifteenth centuries. The major successes in this area over the next three decades were recorded earlier in this essay. From the end of the 1940s, that critical point in the history of Soviet historiography, Cherepnin's road to the Academy was still long. ${ }^{130}$ The story of these decades is a complex one, not susceptible of easy generalization. To tell it adequately will require not only serious study of Cherepnin's immense scholarly legacy but deep knowledge of the struggles of Soviet historians in the larger movement of Soviet history to survive and surmount the consequences of Stalin's rule. The significance of Lev Vladimirovich Cherepnin for the Soviet historical discipline, both as a distinguished scholar and as a moral example, argues that this story be told.

130. Records of the Academy of Sciences would surely indicate that Cherepnin was nominated for the rank of academician well before it was granted in 1972. The range, volume, and importance of his scholarship suggests, at the very least, that he was eligible for nomination following the publication of his monograph on the formation of the Russian centralized state (Obrazovanie Russkogo tsentralizovannogo gosudarstva $v$ XIV-XVI vv. (Moscow, 1960). 